\title{
MEDIJSKA ANALIZA SADRŽAJA ONLINE MEDIJA O FENOMENU SUVREMENOG ISELJAVANJA IZ HRVATSKE
}

\author{
Tado Jurić, Lucija Kardaš, Anja Bakota \\ UDK: 303.64:004.738.5]:331.576(497.5)“2018/219“ \\ Hrvatsko katoličko sveučilište, Zagreb \\ tado.juric@unicath.hr \\ https://doi.org/10.34075/cs.55.3.3 \\ Pregledni znanstveni rad \\ Rad zaprimljen $1 / 2020$.
}

\section{Sažetak}

U radu su predstavljeni rezultati istraživanja analize hrvatskih online medija (web portali) o temi iseljavanja iz Hrvatske. Istraživani su koncept $i$ slika o iseljavanju Hrvata gledani/prikazivani kroz prizmu medija u Hrvatskoj. Tema „iseljavanje iz Hrvatske” analizirana je u člancima sljedećih hrvatskih web portala: Večernji list, 24 sata $i$ Index.hr te Deutsche Welle, međunarodnom njemačkom javnom medijskom servisu. Analiza medija provodila se od listopada 2018. do siječnja 2019. Mediji su izabrani po kriteriju čitanosti te opsega i dostupnosti medijskim publikama. Korištena je zadana matrica istraživanja podijeljena u šest kategorija gdje su se na navedenim portalima analizirali članci metodom analize diskursa. Analizom medijskog sadržaja kodirana su i kategorizirana 152 analizirana članka. Prema zadanim kategorijama istraživane su: opće značajke članaka, vrijednosna orijentacija, odnos autora prema iseljavanju $i$ zastupljenost pojma u članku, naslovi, grafički prikazi u člancima te komentari čitatelja na članak.

Većina objavljenih tekstova o iseljavanju iz Hrvatske napisana je u negativnom kontekstu. Clanci pak o pozitivnim iskustvima preseljenja i odlaska u drugu državu zaista potiču daljnje iseljavanje, odnosno neodlučne potiču na razmišljanje o opciji iseljavanja. Zaključujemo kako mediji koji djeluju u Hrvatskoj jesu pristrani pri prikazivanju teme iseljavanja, jer je vidljivo da su stavovi, odabir osoba za razgovore i citate kao i subjektivnost prisutni u većini članaka. S druge strane, svakako uočavamo i pozitivnu ulogu koju igraju mediji u hrvatskom društvu, čemu svjedoči činjenica da su mediji otvorili više ključnih društvenih tema od samih institucija i službi kojima je to u opisu posla te da svakako djeluju i kao konstruktivan društveni korektiv.

Ključne riječi: iseljavanje, iseljavanje iz Hrvatske, iseljavanje Hrvata, mediji, javno mnijenje, utjecaj medija na iseljavanje. 


\section{UVOD - TEORIJSKA PODLOGA}

Mediji danas više nemaju samo klasičnu ulogu informiranja nego oni oblikuju javno mnijenje i društvene silnice sukladno određenim društvenim i kulturnim obrascima. Povrh svega često imaju u mnogim relevantnim pitanjima izraženo drukčije stavove od hrvatske građanske javnosti (Tanjić, 2017, 2).

„Osim što izvršavaju važnu funkciju informiranja javnosti o svim važnim događajima iz našeg društvenog okruženja, mediji te iste događaje, osobito ako su po nečemu specifični, neočekivani, intrigantni i nerutinski (krizni), koriste najprije za popunjavanje svojih naslovnica i 'headlinea' koji su samo 'vrata spektakla' i podložni su drugačijim pravilima od onih što vrijede za 'obične' vijesti i događaje. Određeni mediji jedva čekaju, zapravo i priželjkuju upravo takve teme. Ali pitanje je kolika je stvarna društvena odgovornost tih medija, ako zanemarimo sva pisana pravila teoretičara medija o poštivanju i vjerodostojnom izvještavanju javnosti. A ono što bi nas najviše trebalo zanimati je kako se tretira odgovornost medija za pogrešno objavljenu informaciju, objavljivanje neprovjerene informacije, objavljivanje fotografija koje zadiru u osobnost i privatnost pojedinca, osobito u trenutku stradanja kada je pojedinac potencijalna žrtva." (Rešetar, 2018:14)

Tisak, odnosno novine, koje su u počecima služile trgovcima kao glasilo koje pomaže pri poslovanju, u 17. st. postale su javno dostupne, čime je započeo proces formiranja javne sfere i javnog mnijenja (Habermas, 1962.). Već dulje vrijeme svjedočimo ekspanziji tehnologije te se promjenom i modernizacijom mijenja i klasični tisak. Mediji svoju budućnost vide u razvoju novih tehnologija i na Internetu, čemu u prilog svjedoči i činjenica o stalnom rastu broja čitatelja na web portalima, a sve manjem broju naklada tiskanih izdanja novina. Masovna komunikacija omogućuje prijenos informacija širokoj publici, a kao takva u dodiru je s različitim ideologijama. Tehnološki razvoj doveo je do ekspanzije medija, lake uporabe i brze dostupnosti gotovo svakome.

Danas, međutim, mediji sve manje imaju posredničku ulogu prenošenja informacija do recipijenata, a sve više ulogu instrumenta u rukama onih koji kreiraju javno mnijenje. (Kunczik i Zipfel, 2006.)

„Mediji mogu nešto prikriti ili otkriti, mogu stvarati osjećaj pripadnosti i sudjelovanja ili poticati osjećaj izoliranosti i odvojenosti. Oni to čine tako da dovode u pitanje uobičajenu podjelu na područja koja su dostupna javnosti, dakle ono što se odvi- 
ja 'na sceni', od onoga što se odvija 'iza scene', tj. što bi trebalo biti rezervirano samo za određene kategorije ljudi. Naime, ponašanja i djelovanja koja su pripadala isključivo područjima privatnosti sada postaju vidljiva svima jer se odvijaju pred svjetlima javnosti. Time postaju dostupna i onim kategorijama ljudi kojima je prije pristup u određene sfere bio ograničen jer su bile 'zaštićene'." (Valković, 2016:99-105.)

Osim što izvršavaju važnu funkciju informiranja javnosti o svim važnim događajima iz našeg društvenog okruženja, mediji te iste događaje, osobito ako su po nečemu specifični, neočekivani, intrigantni i nerutinski (krizni), koriste najprije za popunjavanje svojih naslovnica i headlinea koji su samo „vrata spektakla” i podložni su drugačijim pravilima od onih koja vrijede za „obične” vijesti i događaje. Određeni mediji jedva čekaju, zapravo i priželjkuju upravo takve teme. Ali pitanje je kolika je stvarna društvena odgovornost tih medija, zanemarimo li sva pisana pravila teoretičara medija o poštivanju i vjerodostojnom izvještavanju javnosti. A ono što bi nas najviše trebalo zanimati jest kako se tretira odgovornost medija za pogrešno objavljenu informaciju, objavljivanje neprovjerene informacije, objavljivanje fotografija koje zadiru u osobnost i privatnost pojedinca, osobito u trenutku stradanja kada je pojedinac potencijalna žrtva. (Rešetar, 2018:14)

Mediji danas mogu izravno odlučivati o zastupljenosti određenih tema $\mathrm{u}$ javnosti te o njihovom utjecaju na javnost. Pomoću različitih strategija oni manipuliraju javnim mnijenjem određujući kako će određena tema biti prezentirana, koliko će biti zastupljena te tko će i kada govoriti o temi. Nekoliko teorija medijskog utjecaja na javnost spominje načine kojima mediji određuju o temama $u$ javnosti. Primjerice teorija dnevnog reda (Kunczik i Zipfel, 2006.) govori kako mediji oblikovanjem sadržaja, izborom i plasmanom informacija usmjeravaju pozornost javnosti na određene teme i određuju najvažnija društvena pitanja. Medijskim se sadržajem ne određuje što publika misli, nego o čemu misli. S druge strane, teorija ovisnosti o medijima kaže kako mediji imaju ili umjeren ili snažan utjecaj na formiranje stavova i javnog mišljenja. Ako osoba ne raspolaže informacijama ili ne posjeduje stav o određenom pitanju, tada mediji mogu imati velik utjecaj na formiranje mišljenja. Teorija okvira bavi se načinom na koji se ljudi u komunikaciji koriste interpretacijskim okvirima, tj. odabiru dijelove informacije i čine ih značajnijima u odnosu na ostatak informacija. U medijskoj komunikaciji okvire koriste novinari kao komunikatori i publika koja je primatelj informacije. (Kunczik i Zipfel, 2006.) 
Rešetar navodi da su novi mediji sve više personalizirani, tj. predviđeni za individualno konzumiranje. Vrlo često kriterij odabira postaje korisnost ili pak aktualnost određenog sadržaja te navodi kako se nerijetko događa da se, unatoč dostupnosti velikog broja informacija, osoba osjeća nedovoljno spremnom ili nedovoljno odlučnom za djelovanje u vidu ostvarenja društvenih ciljeva. Taj se manjak posebno zapaža kada je potrebno aktivno djelovati. (Rešetar, 2018:13-14)

„Svakog dana u medijima čitamo o novoj poraznoj statistici iseljavanja iz Hrvatske. Negativan migracijski saldo uzeo je maha proteklih nekoliko godina, točnije od ulaska Hrvatske u Europsku uniju, i ne staje. Postavlja se pitanje tko je sve odgovoran za iseljavanje građana. Prozivaju se i mediji da se za poticanje iseljavanja služe lažnim informacijama o životu koji se nudi novim iseljenicima te da se Hrvatsku prikazuje zemljom bez budućnosti, zemljom kriminala i tome slično. Službene statistike bilježe naizgled jednu nelogičnost - u Hrvatskoj istodobno pada i zaposlenost i nezaposlenost. Dostupnost transportnih sredstava i tehničko-prometna revolucija utjecale su na porast sklonosti traženju zarade i boljeg života u tuđini. Jednako tako, i dostupnost informacija ima veliki značaj u procesima migracije te su potencijalni iseljenici svjesniji onoga što se događa u njihovoj okolini zbog dostupnosti svih podataka koji ih zanimaju. Najšira je publika izložena brojnim informacijama na temeljima kojih grade predodžbu o trenutačnom stanju i zbivanjima u svojoj okolini. Naime, čovjek svoje gledanje na svijet oko sebe oblikuje na temelju informacije koje ima o njemu.” (Rešetar, 2018:1)

Ovo istraživanje temelji se na promatranju utjecaja medija u procesu iseljavanja Hrvata, te se bavi dvama pitanjima: kakav utjecaj mediji imaju na iseljavanje Hrvata, potiču li javnost da se informira o onome što se događa u državi te stvaraju li namjerno atmosferu pogodnu za dodatno iseljavanje stanovništva?

„Istraživanje upućuje na jasnu vezu između političke etike, slabih institucija i iseljavanja. Većina naših ispitanika slaže se da Hrvatska nije društvo koje svojim građanima osigurava dostojan život i perspektivu, odnosno pravnu sigurnost, ekonomski prosperitet i mogućnost profesionalnog razvoja. Hrvatskim društvom danas neupitno vlada jedna vrsta moralne panike i kolektivne psihoze, koje su posljedica iseljavanja oko pet posto ukupnog stanovništva, i to u samo protekle četiri godine. Posebni problem u fenomenu iseljavanja čine mediji, koji cijelu temu prikazuju pristrano i kao da navijaju za odlazak ljudi iz zemlje. 
Tako se u društvu stvara slika da su oni koji su otišli uspjeli, a da su oni koji ostaju gubitnici.” (Jurić, 2017:362)

Upravo zbog navedenog zabrinjavajućeg procesa i posljedica koje ima po stanovništvo Hrvatske, potrebno je zapitati se o ulozi medija u procesu iseljavanja. Stoga i provodimo ovu analizu medija kojoj je cilj pokazati na koji način hrvatski mediji u javnosti prikazuju iseljavanje, utječu li dodatno na iseljavanje svojim djelovanjem, te u kojoj su mjeri pristrani pri svojim izvještavanjima.

Svakako valja spomenuti vrijedan rad autorice Rešetar, koja je na sličan način analizirala medije i njihov utjecaj na iseljavanje. Autorica navodi svoja istraživačka pitanja te hipoteze, temeljenim na ciljevima. Prva hipoteza pretpostavlja kako u posljednje vrijeme portali objavljuju sve više tekstova o iseljavanju, dok druga pretpostavlja kako politička orijentacija portala određuje kakvi će se članci i u kojem broju objavljivati s obzirom na trenutačno vladajuću političku opciju. Treća hipoteza uključuje pretpostavku da je većina objavljenih tekstova o iseljavanju iz Hrvatske napisana u negativnom kontekstu (Rešetar, 2018.). Nadalje, autorica navodi kako odabire pet hrvatskih portala i analizira koliko su članaka o iseljavanju stanovništva iz RH objavili proteklih godina; početna je točka istraživanja 1. srpnja 2013. godine, kada je Hrvatska ušla u Europsku uniju te joj se samim time otvorilo europsko tržište rada, a završna točka uključuje 31. srpnja 2018. godine. Također se, kao i mi, koristi metodom analize sadržaja, ali provodi anketu online upitnikom kojom su prikupljena razmišljanja i stavovi ispitanika u Republici Hrvatskoj o utjecaju medija na raspoloženje ljudi u vezi s iseljavanjem iz Hrvatske. U analizu uključuje portale Index, 24sata, Tportal, Dneunik te Narod.hr, što je rezultiralo sa 548 analiziranih članaka (Rešetar, 2018.).

Nakon provedene analize autorica zaključuje kako je većina svih članaka na portalima bila napisana u negativnome kontekstu, te kako portali objavljuju više članaka o problematici iseljavanja kada je ono masovnije započelo, te potvrđuje prvu i treću hipotezu. Druga hipoteza, koja uključuje političku orijentiranost portala, mogla se odnositi samo na portale Index i Narod.hr, koje identificira kao „ljevičarski” i „desničarski” te zaključuje da politička orijentacija portala utječe na sadržaj članka. Uzimajući u obzir i analizu sadržaja i rezultate online anketnog upitnika, autorica zaključuje kako medijska publika medijski sadržaj ne shvaća toliko negativno, te kako $60 \%$ ispitanih smatra da mediji objavljivanjem takvih članaka ne stvaraju negativno ozračje u Hrvatskoj. Nadalje, većina smatra kako mediji ne objavljuju previše članaka o temi iseljavanja, 
što znači da žele biti informirani o događajima u zemlji. Osobito značajnim smatramo podatak kako 81,6\% ispitanika misli da ih članci o pozitivnim iskustvima preseljenja i odlaska u drugu državu potiču da i sami počnu razmišljati o odlasku (Rešetar, 2018).

\section{MetodologiJa}

Analizu medija provodili smo od listopada 2018. do siječnja 2019. godine, na četiri internetska portala na hrvatskome jeziku. Portali su odabrani kao, prema ocjeni autora, najčitaniji domaći portali (24sata, Večernji list, Index.hr) te Deutsche Welle, kao međunarodni njemački javni medijski servis. Obrađeno je 139 članaka s tematikom iseljavanja Hrvata, od kojih se 36 članaka odnosi na portal 24sata, 25 na portal Deutsche Welle, Index.hr uključuje 40 članaka, a Večernji list 38 članaka.

Članci su birani na način da se na portalima unosila ključna riječ „iseljavanje”, „Hrvata”, „Hrvatska”, a zatim su se od ponuđenih članaka odabirali članci koji su izravno vezani za temu iseljavanja Hrvata ili gdje je intonacija članka upućivala na raspravu o masovnom iseljavanju.

Istraživačka matrica uključuje 13 istraživačkih pitanja, koja se odnose na:

- funkcija priloga

- prikaz Hrvatske i iseljeničkih zemalja

- izvor informacija

- selekciju izvora informacija

- citiranu osobu

- reakcije u komentarima

- zemlje o kojima se najviše izvještava

- razloge iseljavanja

- stavove i informacije u članku,

- tip naslova

- informacije i stavove iznesene u članku

- orijentaciju na čitatelje

- otvorenost prema stavovima.

Funkcija priloga odabrana je kao bitna za istraživačka pitanja, jer je bilo potrebno razlučiti članke koji su isključivo kritički od onih članaka koji su kritički, ali donose i informacije iz imenovanih izvora, te onih članaka koji donose samo informacije, bez dijeljenja subjektivnog mišljenja autora. Prikaz Hrvatske i iseljeničkih zemalja 
dao je informaciju o načinu na koji se u člancima prikazuje Hrvatska, kao negativna ili kao pozitivna ili su informacije bile neutralne, te $u$ kojoj se mjeri i kako piše o iseljeničkim zemljama, kao i piše li se to u negativnom, pozitivnom ili nikakvom kontekstu osim pružanja temeljnih informacija. Izvori informacija i selekcija izvora informacija te citirane osobe uključeni su kako bi se uvidjelo u kojoj mjeri su članci pisani na temelju informacija koje su provjerene i koje dolaze iz ispravnih statističkih informacija, te odakle te informacije dolaze, ili se radi samo o preuzetim, neprovjerenim informacijama, kao i o preferencijalnom biranju sugovornika, ovisno o tome kakav se ton članka želi postići. Nadalje, za promatranje je bilo bitno utvrditi kakvi su komentari ispod članaka ako ih ima, da bi se uvidjelo kako čitatelji reagiraju na članak ovisno i o njegovom kontekstu, te uspijeva li članak postići željeni stav koji se prenosi tekstom ako se radi o negativno ili pozitivno orijentiranom članku. Predmet zanimanja bile su i zemlje o kojima se najviše izvještava, kako bi se utvrdilo kamo se Hrvati najviše iseljavaju, te kako bi se pokušao pronaći razlog iseljavanju. Stavovi i informacije $u$ članku pokazuju subjektivnost ili objektivnost članka, a ono što je bitno jest i promatranje orijentacije na čitatelje i otvorenost prema stavovima čitatelja. Autore je zanimalo jesu li članci orijentirani na čitatelja na način da su razumljivi svakom čitatelju, ili se radi o člancima koje može čitati uži krug čitatelja, koji su informiraniji o određenim temama ili terminima. Otvorenost prema stavovima čitatelja očitovala se u tome jesu li autori pri pisanju članka iznosili samo svoje stavove i nametali ih čitateljima, ili je u tekstu bilo prostora da čitatelji sami donesu svoj stav ili zaključke o temi o kojoj se raspravljalo.

Istraživačka matrica podijeljena je u šest podvrsta. Prva od njih obuhvatila je opće značajke članaka u opisane svrhe, odnosno: rubriku portala, vrstu članka, žanr članka, ime autora teksta, interpretaciju u člancima, način prikaza teme, itd., kako bi se opisao članak o kojem se govori. Sljedeća podtema odnosila se na komentare i reakcije čitatelja na članak. Promatrao se broj komentara ispod članka, broj „klikova”, odnosno dijeljenja članka te negativnost prema temi u komentarima ispod članaka. Dijeljenja članka su upućivala na moguću recepciju članka, to jest, ako članak izaziva emocionalnu reakciju, potrebu za dijeljenjem članka s ostalima. Nadalje, istraživanje je nastojalo odrediti stav autora članaka o iseljavanju iz Hrvatske, kontekst u kojem je članak pisan te dubinu i način obrade teme.

Dubina i način obrade teme pojašnjavali su obrađuje li se u tekstu članka mnogo različitih informacija ili su one samo površne 
i jednostrane, te donosi li se više pristupa istoj temi kako bi se odredilo jesu li članci sugestivni ili nude više informacija koje podržavaju različite stavove kako bi se dobila cijela slika o određenoj temi.

Jedna od važnijih podtema bili su i naslovi, odnosno tip naslova te grafička oprema koja se koristila u članku. Tip naslova mogao je ukazivati na senzacionalizam kako bi se privuklo čitatelja da otvori članak, a zatim pročita članak koji jest ili nije subjektivan, ili izaziva emocionalnu reakciju, ili se moglo raditi o načinu privlačenja čitatelja, a potom tekstu napisanom u informativnom stilu. Nastojalo se odrediti kojim se grafičkim sredstvima autori u člancima najviše služe i sadrže li grafike u člancima potpis autora kako bi se utvrdilo pokušava li se slikama ili grafikonima izazvati emocionalna reakcija te jesu li znani autori grafikona koji stoje svojim potpisom iza njih.

Zadnja podtema odnosila se na vrijednosnu orijentaciju, koja je obuhvatila: već spomenutu otvorenost autora prema stavovima čitatelja, postoje li u člancima društveno štetne komunikacijske forme i, ako se autori služe takvim komunikacijskim oblicima, nastojalo se definirati kojim se oblikom služe. Ukoliko su postojale društveno štetne komunikacijske forme, nastojalo se utvrditi kakve: radi li se o kleveti, lažnim informacijama kako bi se prenijela određena poruka, opscenim ili vulgarnim te uvredljivim porukama, pozivanju na određene negativne akcije i neposlušnost, osuđivanju, pozivanju na nasilje ili diskriminaciju i slično.

Na kraju želimo napomenuti da analizirani online portali, Večernji lista, 24sata, Index.hr i Deutsche Welle, nisu u većoj ili manjoj mjeri pristrani od ostalih online portala u Hrvatskoj, niti postoji studija koja bi na to ukazivala. Naša analiza omogućuje samo usporedbu između ova četiri portala međusobno. Naglašavamo da našom analizom ni na koji način ne pogodujemo ni jednoj medijskoj kući niti imamo suradnju s bilo kojom od njih, te da smo analizu napravili prema našim najboljim saznanjima i prema znanstvenom etičkom kodeksu.

\section{REZULTATI}

\subsection{Funkcija priloga}

Funkcija priloga prikazuje općeniti ton analiziranoga članka te upućuje na to je li članak napisan u informativne svrhe, pružajući samo informacije, ili ima edukativnu (s dubljim kontekstom) ili kritičku formu. 


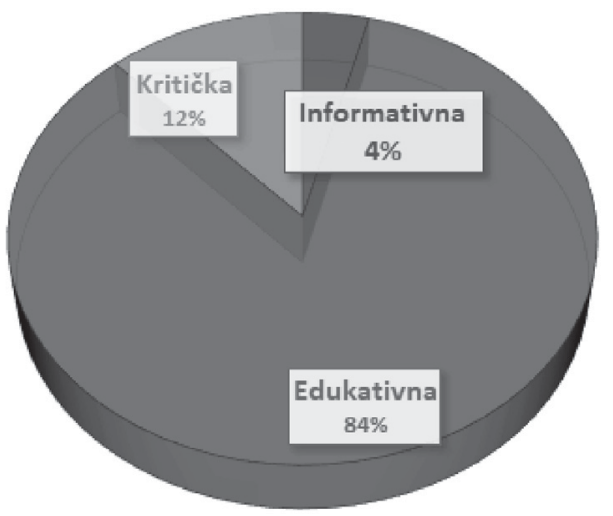

Grafikon 1: Funkcija priloga - Deutsche Welle

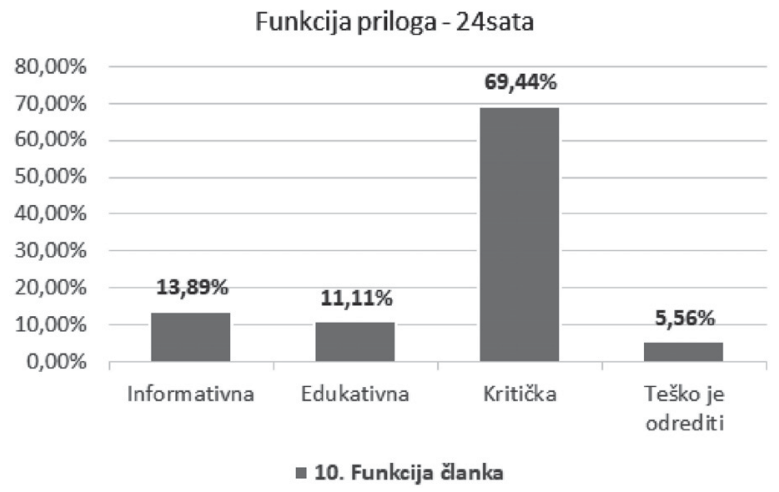

Grafikon 2: Funkcija pril,oga - 24sata

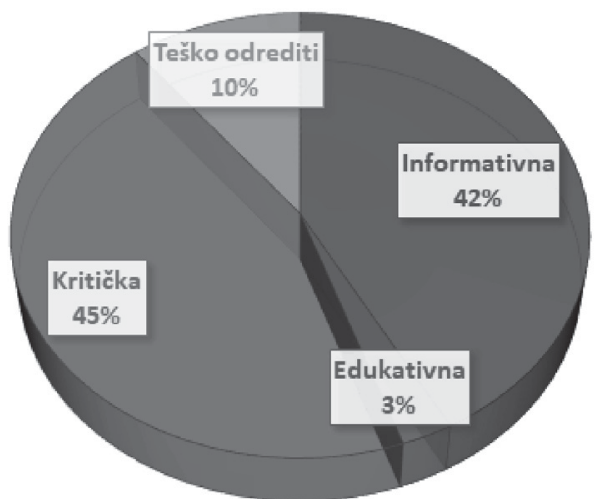

Grafikon 3: Funkcija priloga - Večernji list 


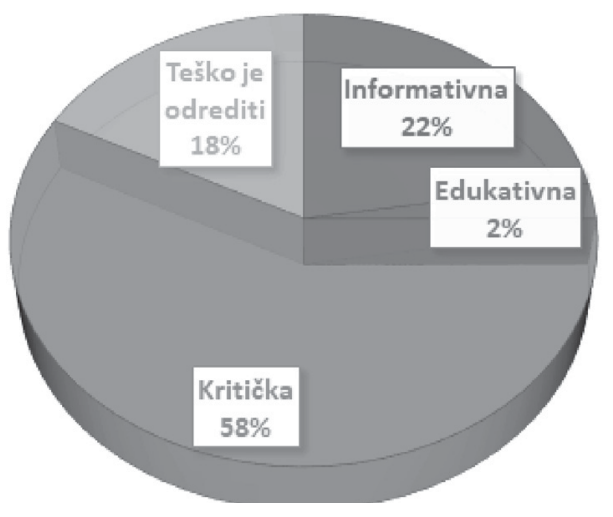

Grafikon 4: Funkcija priloga - Index.hr

Kod analiziranih članaka internetskih portala uviđa se kako većina članaka ima kritičku svrhu, koja se potvrđuje kasnijim stavkama analize. Deutsche Welle u najvećem broju ima edukativne članke (84\%), dok 24sata, Večernji list te Index.hr najveći dio članaka donose u kritičkoj formi.

\subsection{Prikaz Hrvatske i iseljeničkih zemalja}

Prikaz Hrvatske i iseljeničkih zemalja analiziran je kako bi se uvidjelo jesu li članci najviše orijentirani na kritiziranje Hrvatske, a uzdizanje slike iseljeničkih zemalja.

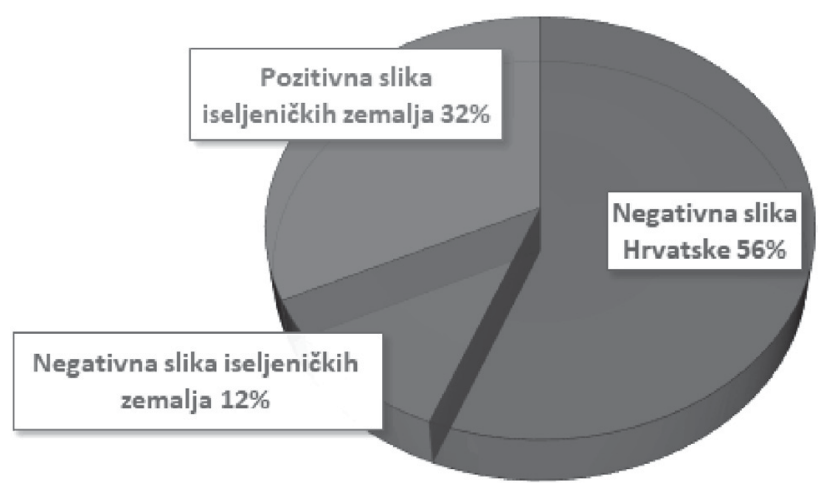

Grafikon 5: Prikaz Hrvatske i iseljeničkih zemalja-Deutsche Welle 


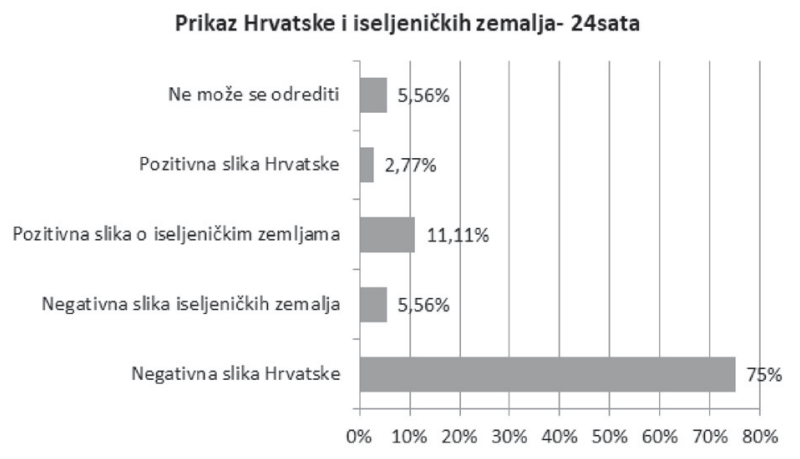

Grafikon 6: Prikaz Hrvatske $i$ iseljeničkih zemalja - 24sata

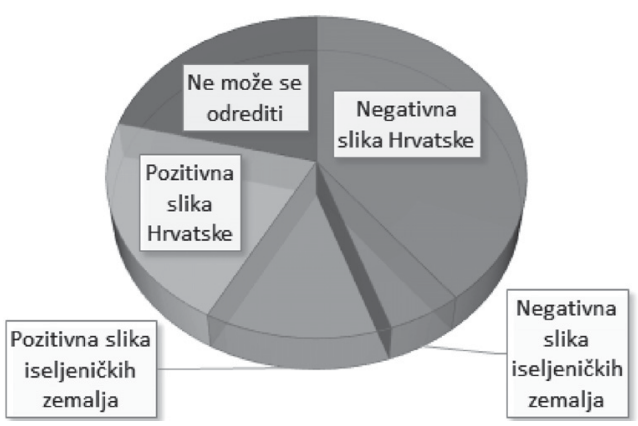

Grafikon 7: Prikaz Hrvatske i iseljeničkih zemalja - Večernji list

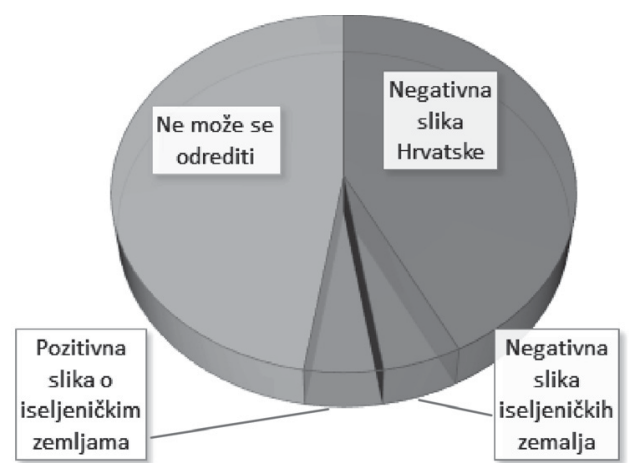

Grafikon 8: Prikaz Hrvatske i iseljeničkih zemalja - Index.hr

Analizom članaka dolazi se do zaključka kako sva četiri portala pokazuju stanje u Hrvatskoj kao negativno, a pozitivna slika Hrvatske očitava se u člancima Večernjeg lista (21\%) te 24sata (2,77\%), i to u manjem postotku. 


\subsection{Izvor informacija}

Izvor informacija predstavlja varijablu koja prikazuje kako se autor koristi izvorima u člancima. Autori mogu imenovati izvore ili pružiti neprovjerene informacije ne imenovavši ni jedan izvor, ili se oslanjajući na citate ili izjave građanina, političara ili stručnih osoba.

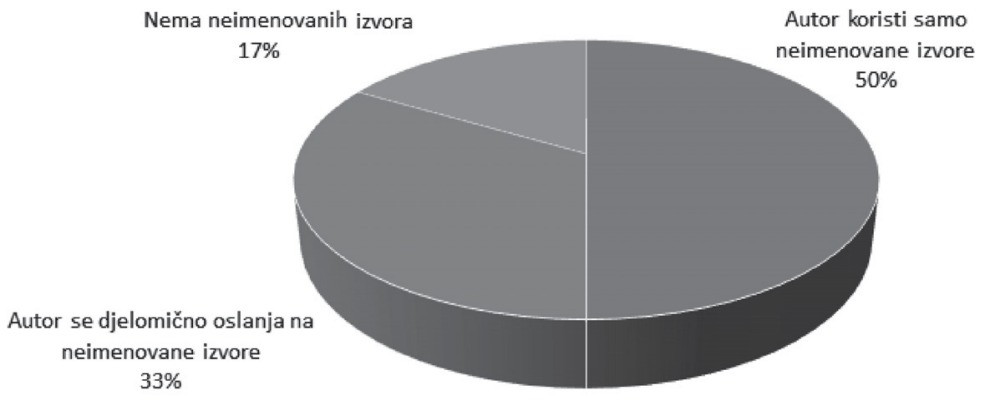

Grafikon 9: Izvori informacija - Deutsche Welle

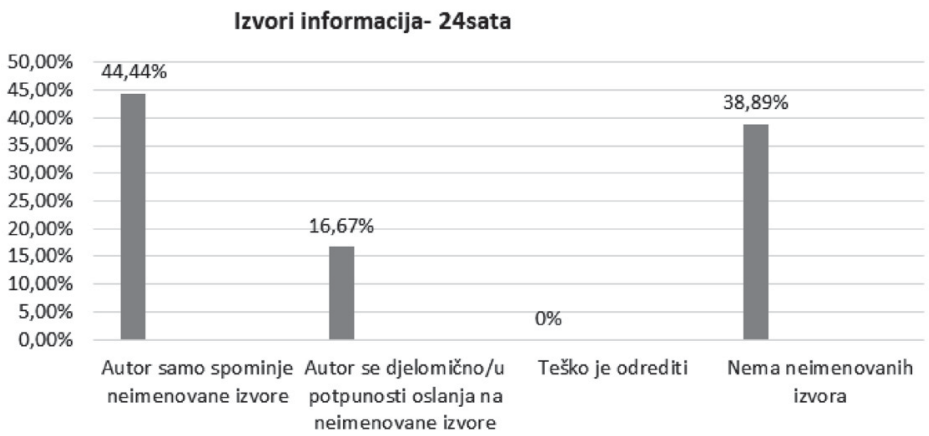

Grafikon 10: Izvori informacija - 24sata

Izvori informacija - Večernji list

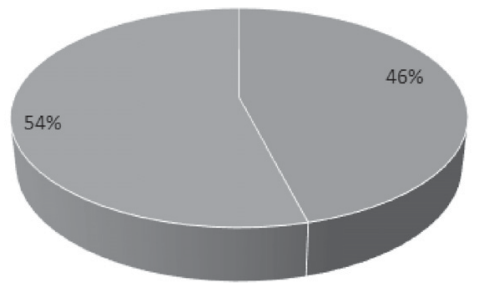

- Autor se djelomično oslanja na neimenovane izvore = " Teško je odrediti

Grafikon 11: Izvori informacija - Večernji list 


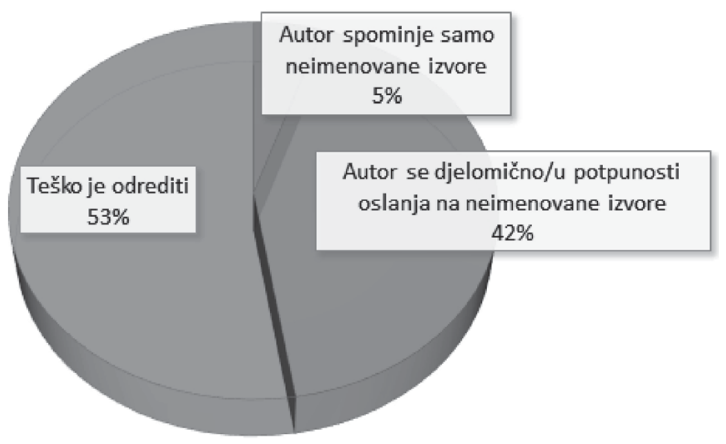

Grafikon 12: Izvori informacija - Index.hr

Kod sva četiri portala, s iznimkom Večernjeg lista, gdje je bilo teško odrediti kakvim se izvorima koristi autor, prevladavaju neimenovani izvori u obliku citata ili razgovora s iseljenicima ili političarima, te se autori u većoj mjeri oslanjaju na neprovjerene izvore. Portal 24sata u značajnijoj mjeri bilježi članke u kojima se ne nalaze neimenovani izvori (39\%).

\subsection{Selekcija izvora informacija}

Selekcija izvora informacija ukazuje na koji način autori koriste izvore pri pisanju članaka - predstavljaju li se u člancima dvije suprotne strane koje zastupaju drugačije stavove te o njima pružaju dokaze, ili se radi o jednostranosti - jednom ponuđenom mišljenju ili stavu bez ponuđenih alternativa.

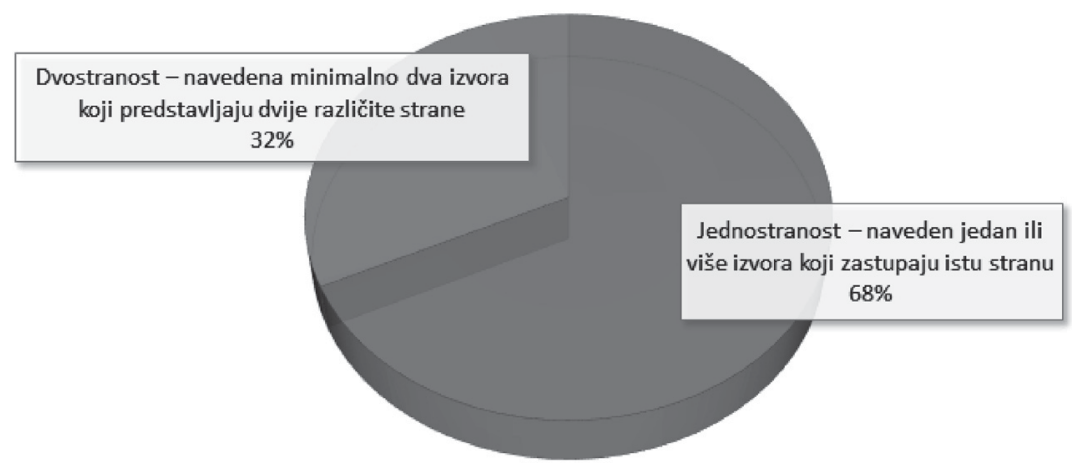

Grafikon 13: Selekcija izvora informacija - Deutsche Welle 


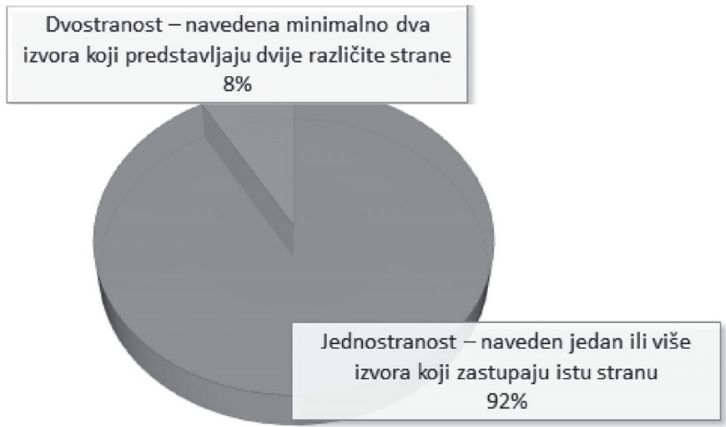

Grafikon 14: Selekcija izvora informacija - 24sata

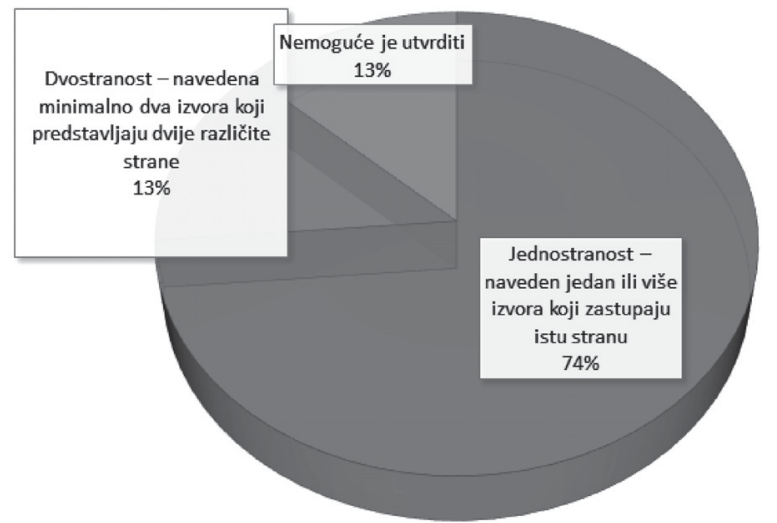

Grafikon 15: Selekcija izvora informacija - Večernji list

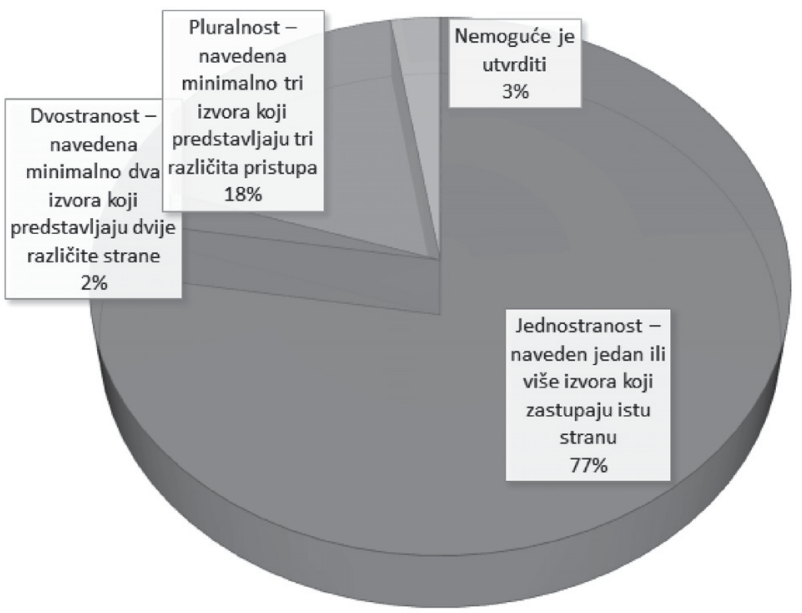

Grafikon 16: Selekcija izvora informacija - Index.hr 
Analizom Deutsche Wellea, 24sata, Večernjeg lista i Indexa.hr moguće je uvidjeti kako se autori koriste samo jednim izvorom ili više njih koji zastupaju istu stranu, čime ne pružaju dovoljno materijala za konstruktivnu raspravu, što potencijalno može imati negativne posljedice na temu o kojoj se raspravlja upravo zbog čitateljeva donošenja zaključaka.

\subsection{Osoba - izvor informacija}

Osoba koja je izvor informacija jest osoba koju se citiralo ili parafraziralo u članku, za potvrdu određene tvrdnje ili dokazivanje pretpostavki.

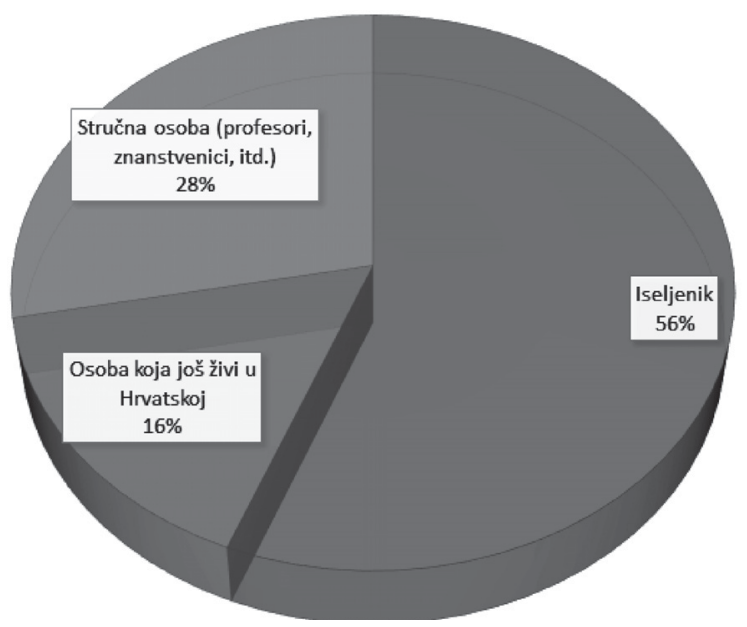

Grafikon 17: Osoba koja je izvor informacija - Deutsche Welle

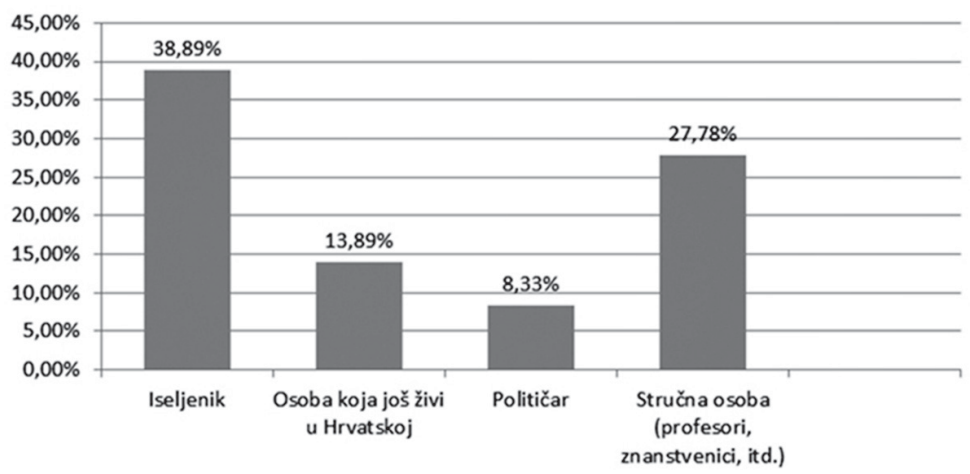

Grafikon 18: Osoba koja je izvor informacija - 24sata 


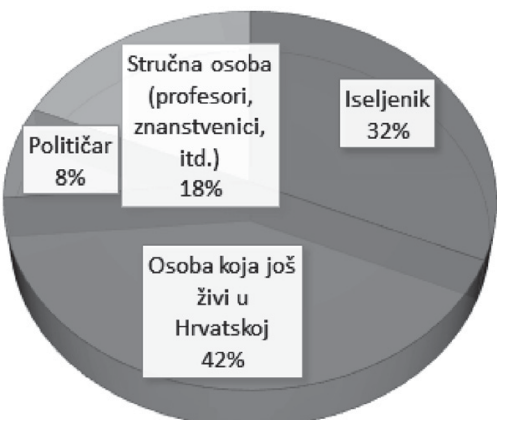

Grafikon 19: Osoba koja je izvor informacija - Večernji list

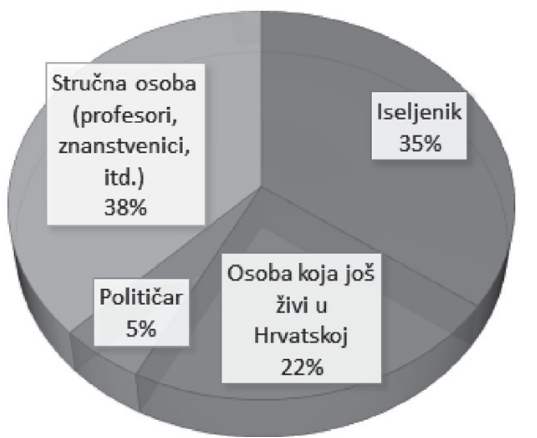

Grafikon 20: Osoba koja je izvor informacija - Index.hr

Portali Deutsche Welle te 24sata najčešće citiraju i parafraziraju iseljenike, dok se Večernji list oslanja na izjave osoba koje još žive u Republici Hrvatskoj, a Index.hr poseže za mišljenjima stručnih osoba ili javnih zavoda.

Nadalje, izjave iseljenika za Deutsche Welle ne nose negativne konotacije kao što je to slučaj sa 24 sata $(86,11 \%)$ i Večernjim listom (40 \%), dok su izjave dane za Index.hr neutralne u postotku od $53 \%$.

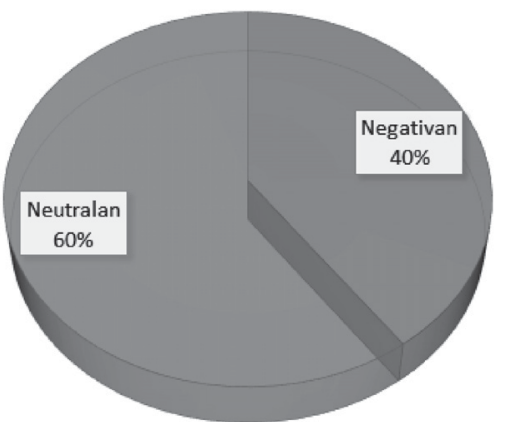

Grafikon 21: Izjava osobe koja je izvor informacija - Deutsche Welle 
19.konotacija citata

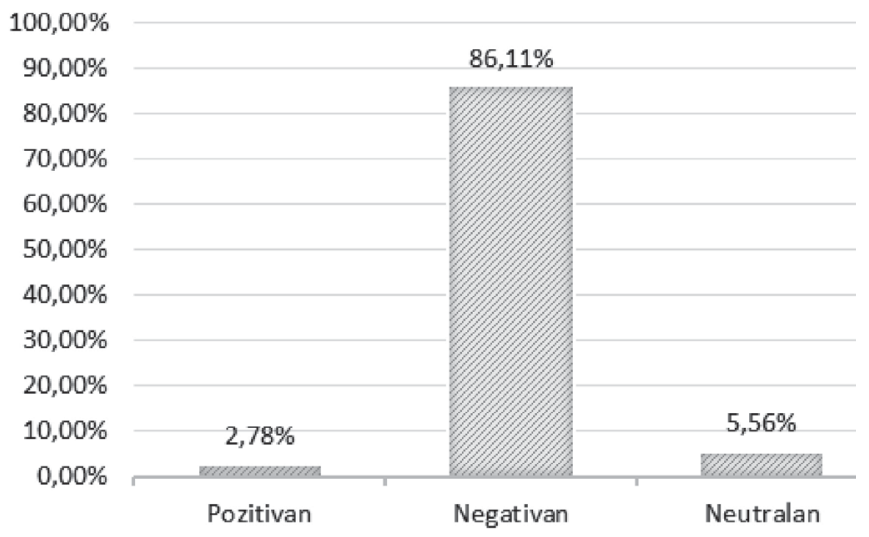

Grafikon 22: Izjava osobe koja je izvor informacija - 24sata

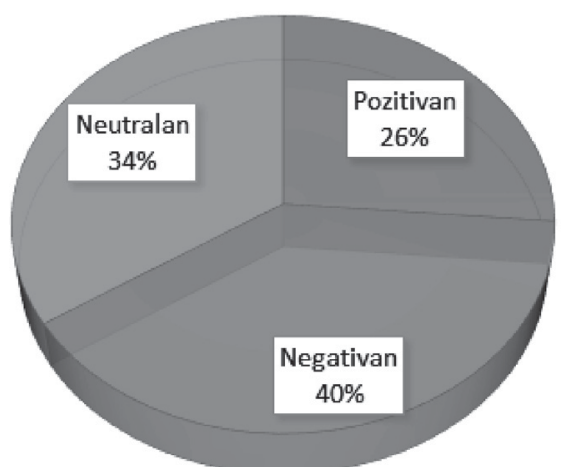

Grafikon 23: Izjava osobe koja je izvor informacija - Večernji list

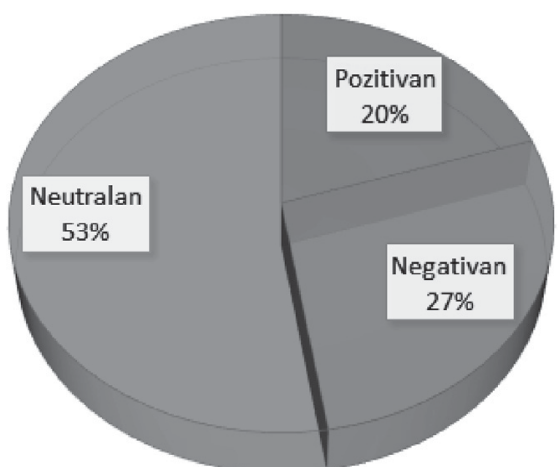

Grafikon 24: Izjava osobe koja je izvor informacija - Index.hr 


\subsection{Reakcije u komentarima}

Reakcije i komentare koje dijele čitatelji portala preko društvenih mreža daju sliku o tome kako je primljena objava članaka te kako javnost reagira na vijesti i informacije objavljenje putem portala, ali su i odraz stvarnog stanja u društvu. Stoga je bitno napomenuti kako komentatori na portalima Večernjeg lista, 24sata te Indexa.hr na članke o iseljavanju ne reagiraju negativno prema iseljenicima, njihovu odlasku ili iseljeničkim zemljama, nego kritiziraju stanje u Republici Hrvatskoj, pa čak i otvoreno najavljuju odlazak i pozivaju na odlazak. Analiza komentara članaka nije mogla biti provedena za portal Deutsche Wellea jer Deutsche Welle u trenutku medijske analize članaka nije imao omogućenu opciju komentiranja članaka, niti pregledavanja komentara.

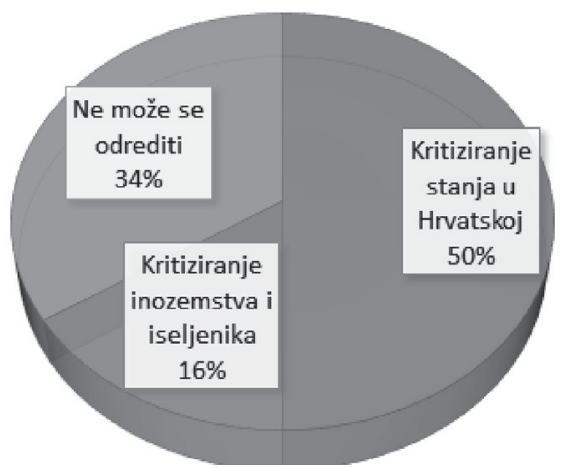

Grafikon 25: Reakcije u komentarima članaka preko društvenih mreža Večernji list

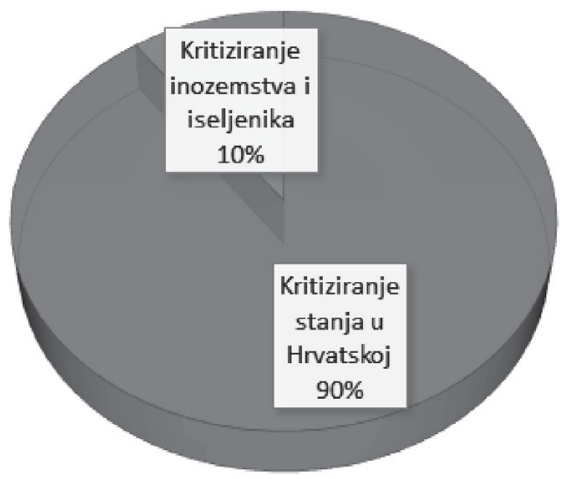

Grafikon 26: Reakcije u komentarima članaka preko društvenih mreža Index.hr 


\subsection{Zemlje o kojima se najviše izvještava}

Zemlje o kojima se najviše izvještava su Njemačka i Irska, s ponekim iznimkama ostalih zemlja u koje odlaze iseljenici, poput Italije, Švedske, Kanade, Amerike, Švicarske, ovisno o kontekstu članka.

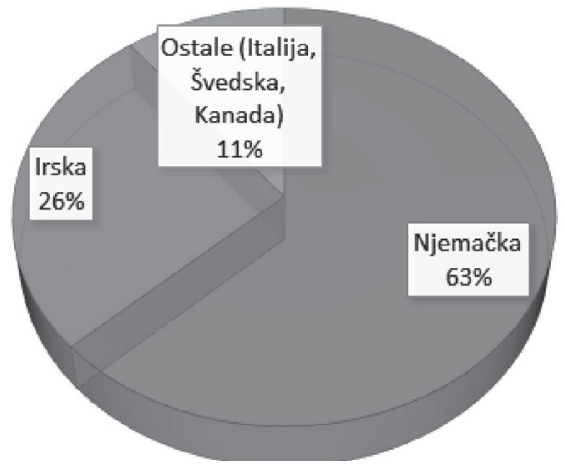

Grafikon 27: Zemlje koje se najviše spominju u člancima-Deutsche Welle

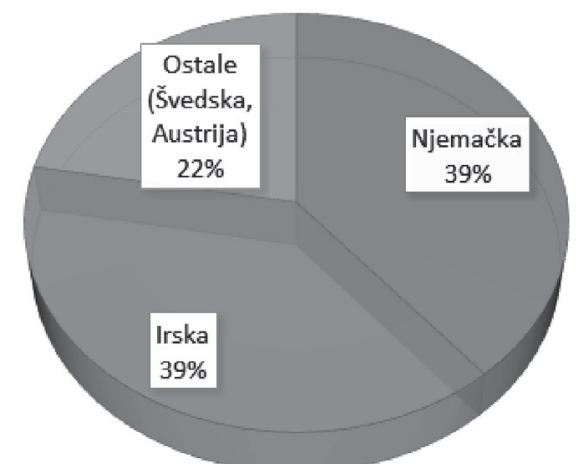

Grafikon 28: Zemlje koje se najviše spominju u člancima - 24sata

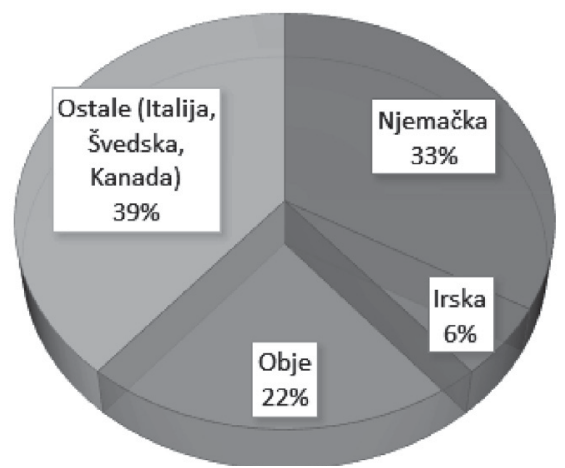

Grafikon 29: Zemlje koje se najviše spominju u člancima - Večernji list 


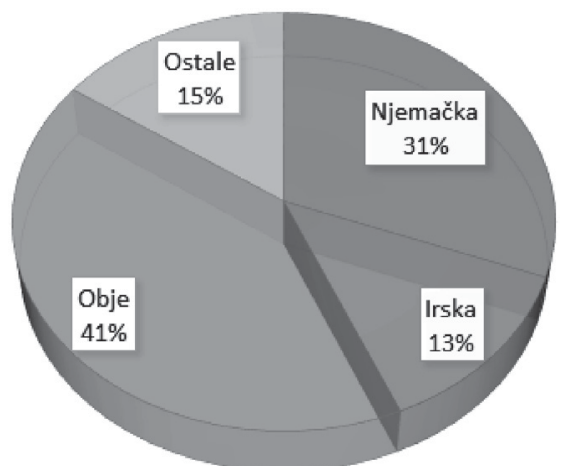

Grafikon 30: Zemlje koje se najviše spominju u člancima - Index.hr

Očekivan je rezultat u kojemu Deutsche Welle najviše izvještava o Njemačkoj i iseljenicima iz Njemačke (63\%), dok ostali portali podjednako u člancima daju primjere iseljenika u Njemačku i Irsku.

\subsection{Razlozi iseljavanja}

Razlozi iseljavanja podijeljeni su u pet kategorija (Jurić, 2018), koje uključuju namjernu produkciju iseljavanja, mrežu iseljavanja i tradiciju iseljavanja Hrvata u Njemačku, slabost institucija i nekompetenciju političkih elita te hrvatsko lobiranje za iseljavanjem. Prema napisima u člancima kao glavni problem i razlozi odlaska ne navodi se ekonomska situacija u državi, nego politički i društveni problemi uzrokovani korupcijom, nepotizmom, kronizmom te nepovjerenjem $u$ institucije.

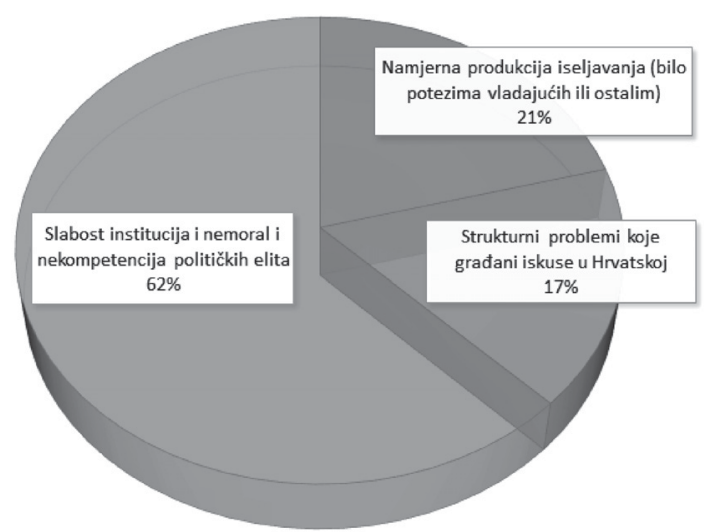

Grafikon 31: Razlozi iseljavanja-Deutsche Welle 


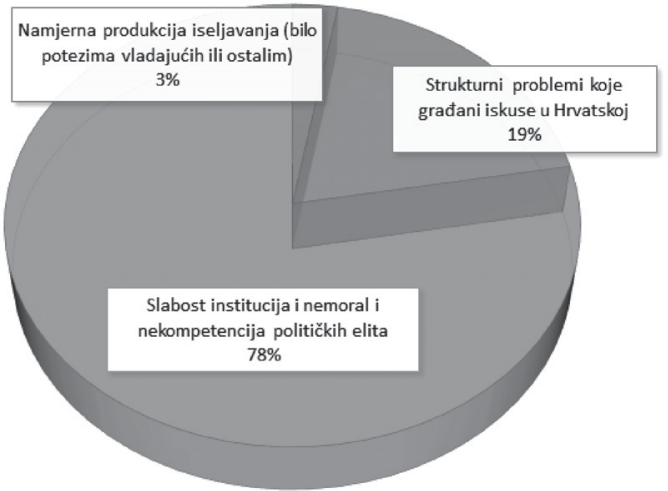

\section{Grafikon 32: Razlozi iseljavanja - 24sata}

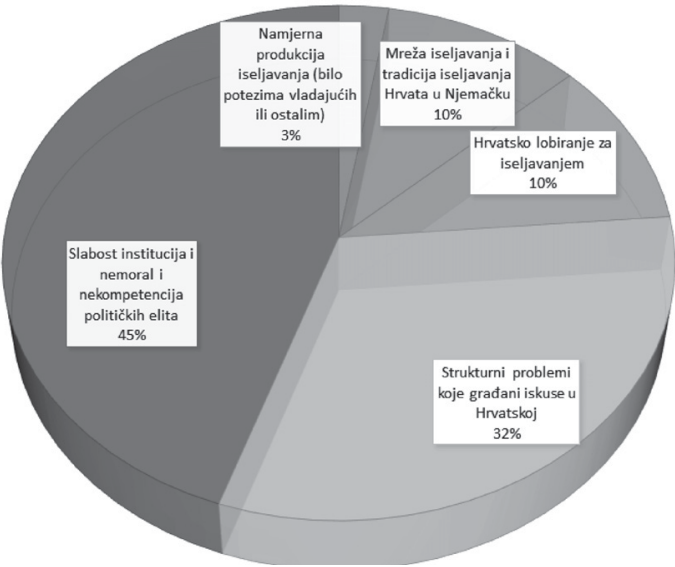

Grafikon 33: Razlozi iseljavanja - Večernji list

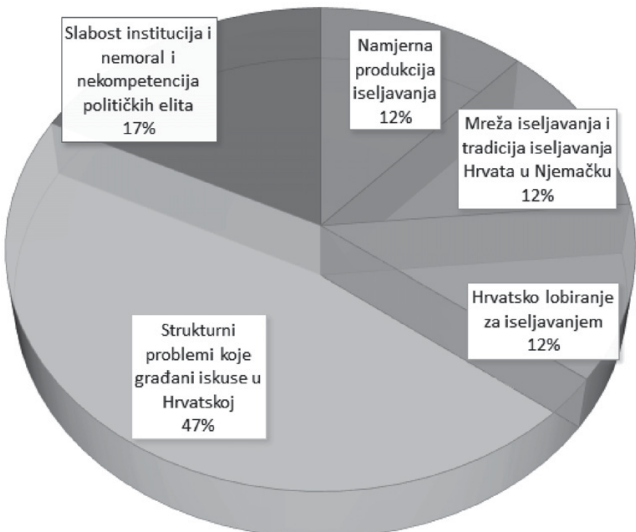

Grafikon 34: Razlozi iseljavanja - Index.hr 
Kod opisa razloga odlaska Deutsche Welle (62\%) i 24 sata (78 \%) te Večernji list (45 \%) kao razloge iseljavanja ističu društvenu nepravdu, nepovjerenje građana u institucije i pravednu državu, krizu morala te nezadovoljstvo funkcioniranjem države. Index.hr razloge iseljavanja nalazi u strukturnim problemima koje građani iskuse u Hrvatskoj, pri tome misleći na nemogućnost građana da se povežu s drugim mjestima pri zapošljavanju te nemogućnost odlaska iz određene sredine kako bi se poboljšala financijska situacija.

\subsection{Stavovi i informacije u članku}

Potrebno je naglasiti kako je većina članaka na analiziranim portalima pisana iz subjektivne perspektive autora, s iznimkom $\mathrm{Deu}^{-}$ tsche Wellea, koji u većini svojih članaka nudi objektivan pristup (92 \%) s više izvora i informacija, dok portali 24sata, Večernji list te Index.hr pokazuju subjektivan pristup temama, uz površno opisivanje problema (bez dublje analize problema kroz iznošenje stavova stručnjaka, a s naglaskom na citiranjem iseljenika).
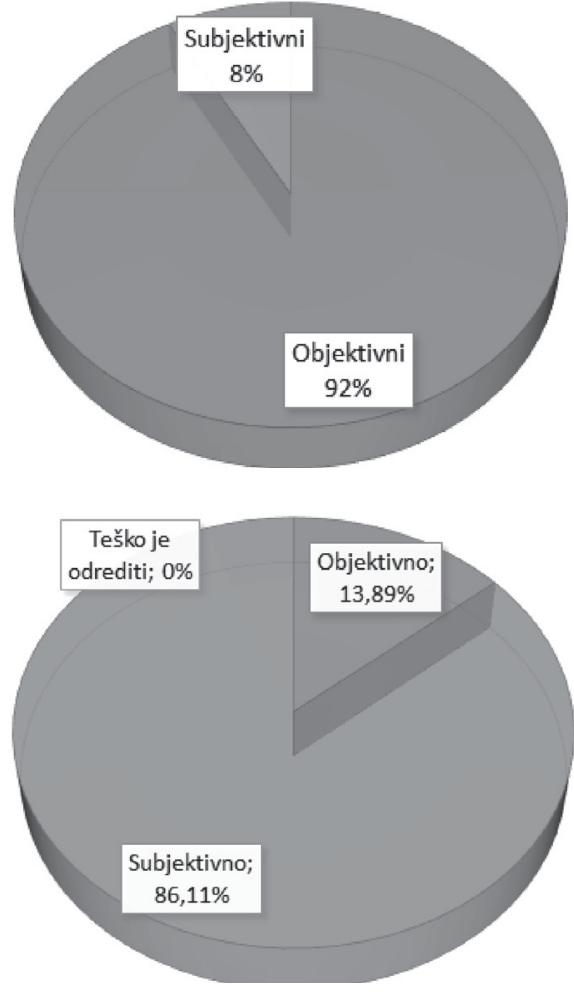

Grafikon 35: Stavovi i informacije u članku - Deutsche Welle

Grafikon 36: Stavovi i informacije u članku - 24sata 


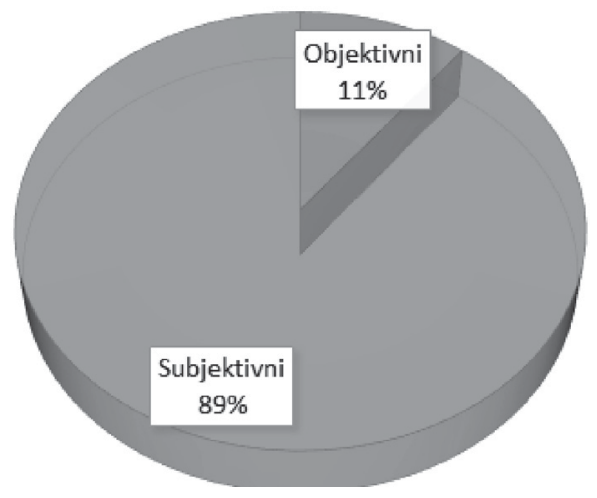

Grafikon 37: Stavovi i informacije u članku - Večernji list

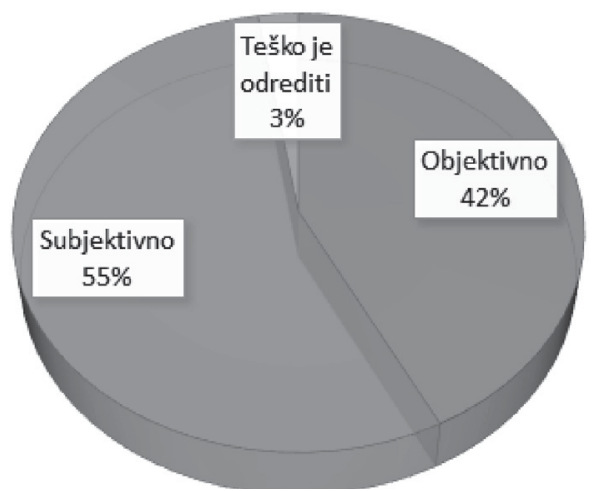

Grafikon 38: Stavovi i informacije u članku - Index.hr

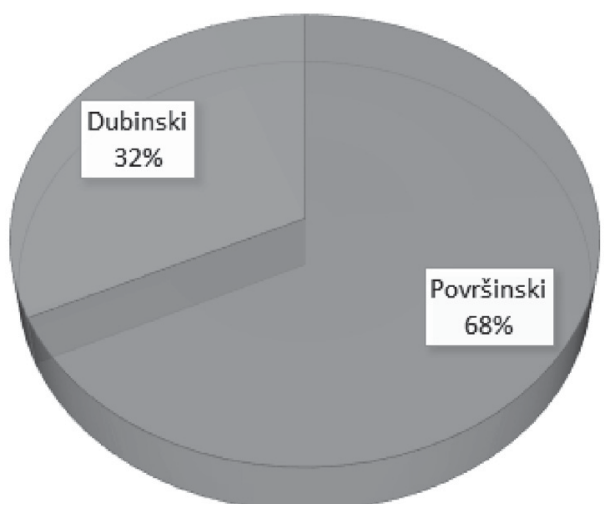

Grafikon 39: Dubina obrade - Deutsche Welle 


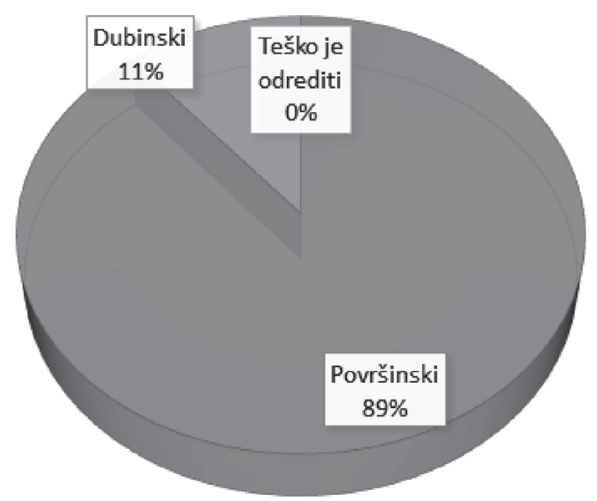

Grafikon 40: Dubina obrade - 24sata

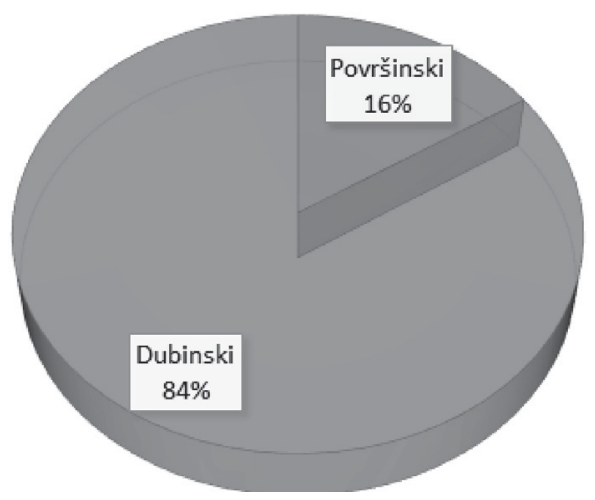

Grafikon 41: Dubina obrade - Večernji list

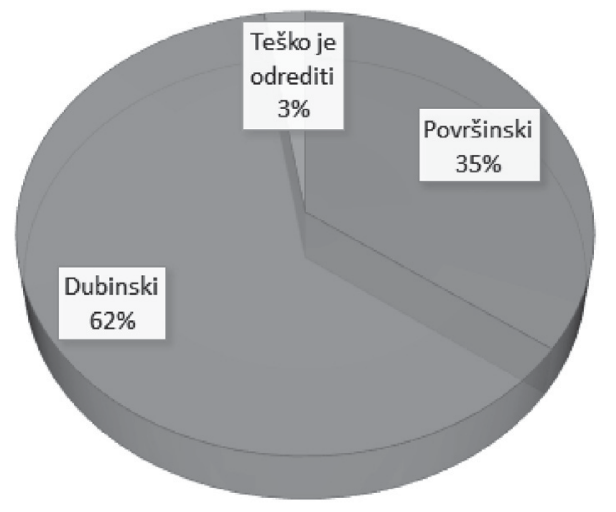

Grafikon 42: Dubina obrade - Indeks.hr 


\subsection{Tip naslova}

Od mogućih naslova, svaki od portala koristi senzacionalističke naslove kako bi privukao čitatelje, a ti naslovi i ne moraju odgovarati težini teme. Iznimka je portal Deutsche Welle, koji u najvećoj mjeri koristi informativni tip naslova (92\%), gdje se izbjegava nepovezanost ili nekoherencija naslova s tekstom članka.

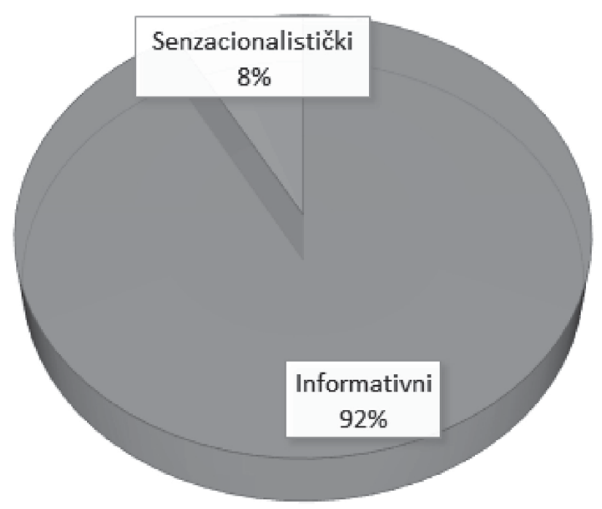

Grafikon 43: Tip naslova - Deutsche Welle

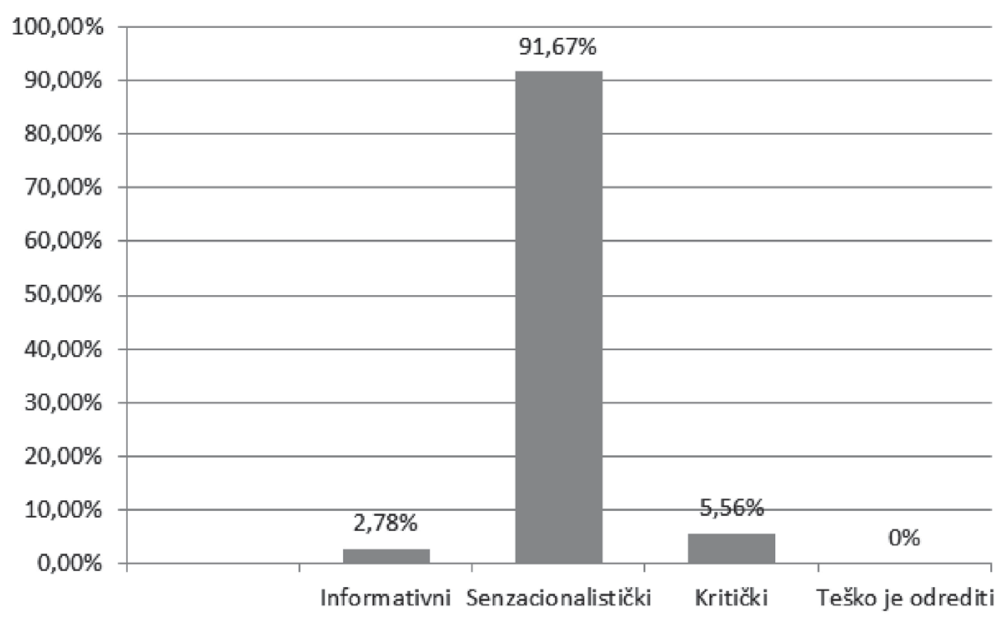

Grafikon 44: Tip naslova - 24sata 


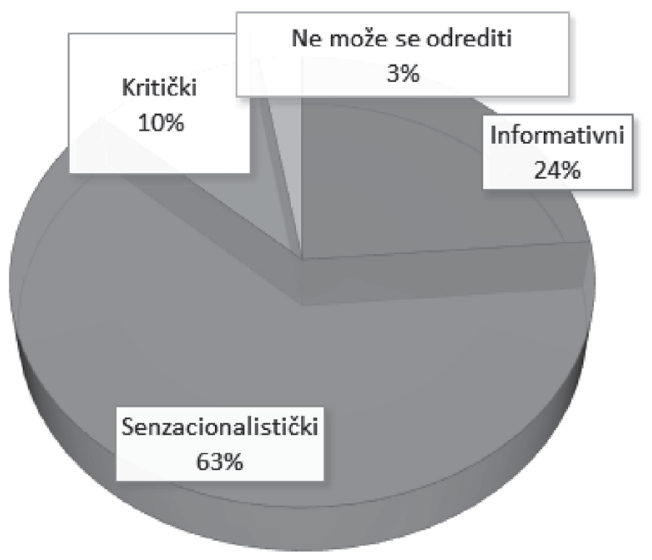

Grafikon 45: Tip naslova - Večernji list

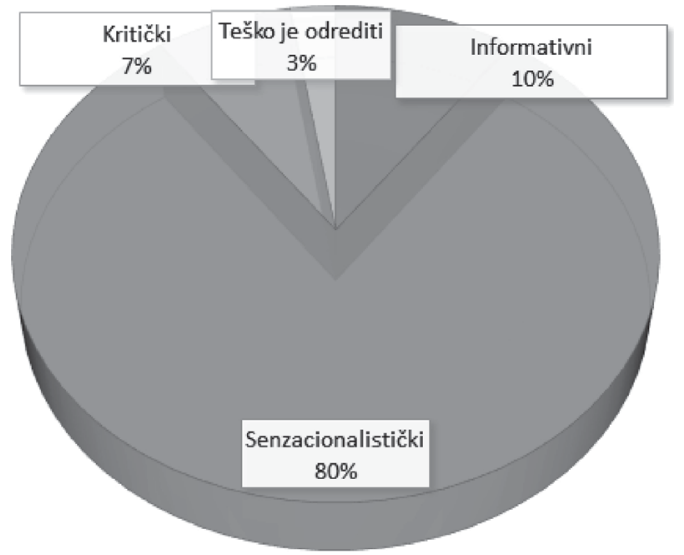

Grafikon 46: Tip naslova - Index.hr

3.11. Informacije i stavovi izneseni u članku i orijentacija na čitatelje

Portali Index.hr (60\%) te 24sata (83\%) u svojim su člancima skloni donositi više stavova negoli informacija koje podupiru izrečeno mišljenje, dok Deutsche Welle te Večernji list pokušavaju unijeti veći broj informacija kako bi poduprli određenu tezu koja se prezentira. Što se tiče orijentacije na čitatelje, sva četiri portala objavljuju članke koji su prikladni za širu publiku te se ne odnose samo na uži krug čitatelja, što znači da je prijenos poruka i informacija lakši jer dopiru do većeg kruga građana. 


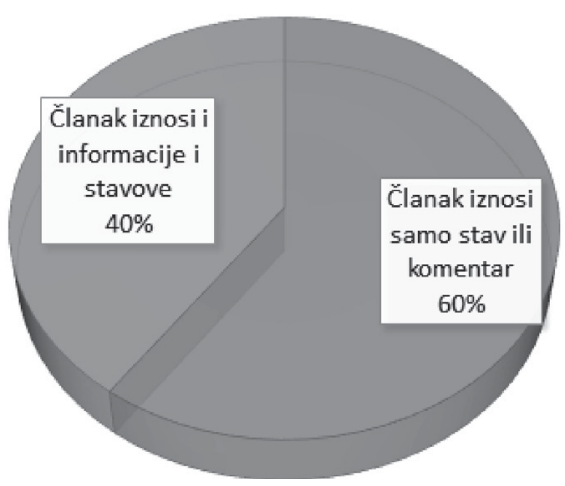

Grafikon 47: Informacije i stavovi izneseni u članku - Deutsche Welle

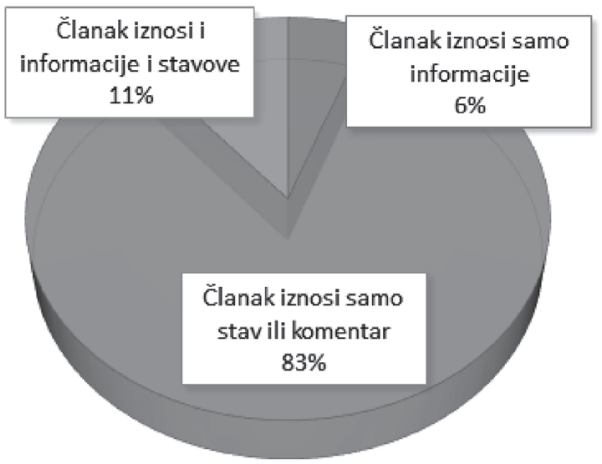

Grafikon 48: Informacije i stavovi izneseni u članku - 24sata

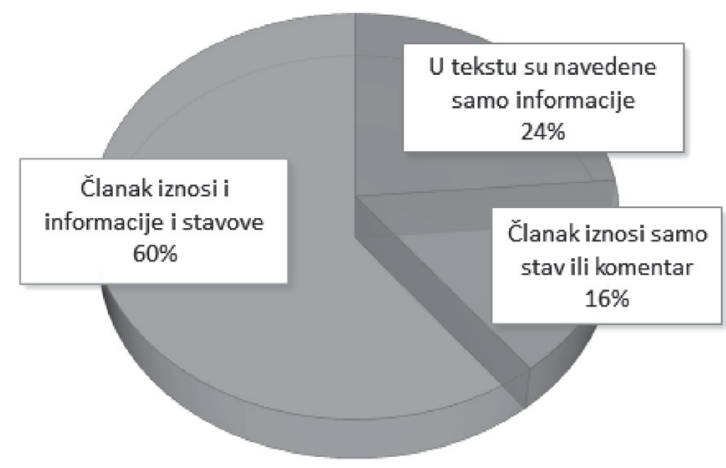

Grafikon 49: Informacije i stavovi izneseni u članku - Večernji list 


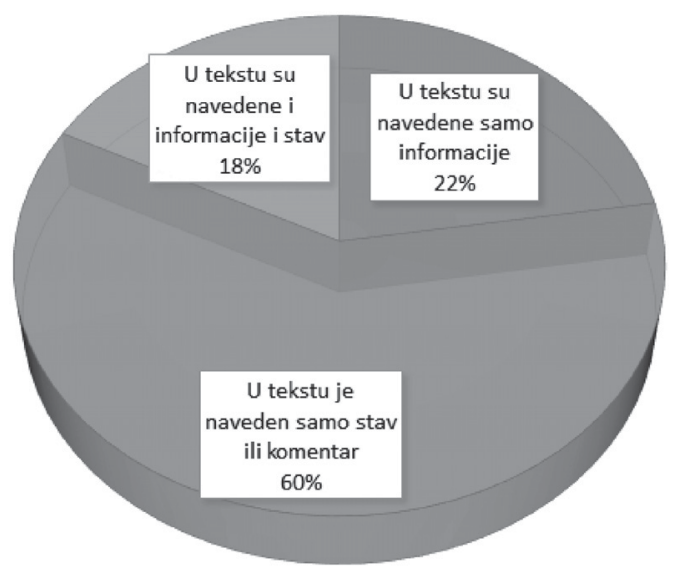

Grafikon 50: Informacije i stavovi izneseni u članku - Index.hr

\subsection{Otvorenost prema stavovima}

Pri otvorenosti u interpretaciji članka Deutsche Welle (100\%) se pokazuje kao najotvoreniji prema čitateljima, budući da ne nameće svoje stavove kao jedine relevantne, dok Večernji list u svojim člancima donosi svoje stavove kao jedine relevantne (55 \%), a čitatelju je ostavljeno manje mjesta za interpretaciju članka na drugi način (40\%). 24sata (92\%) te Index.hr (65\%) ipak donose veću mogućnost interpretacije članaka od Večernjeg lista.

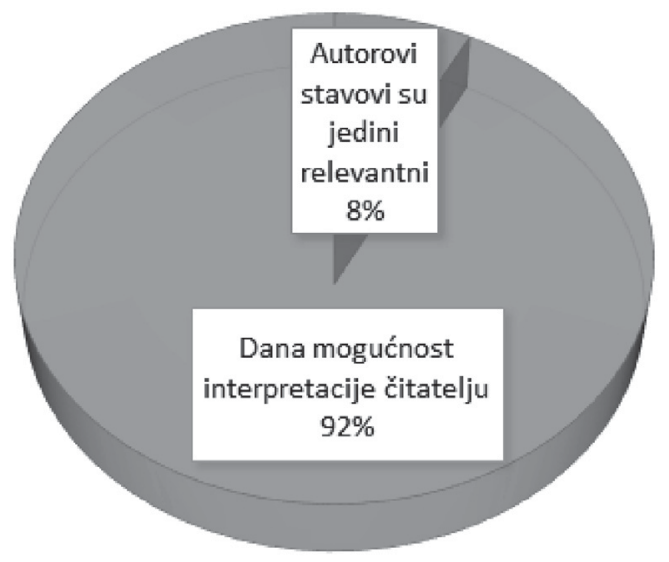

Grafikon 51: „Otvorenost” prema stavovima čitatelja - 24sata 


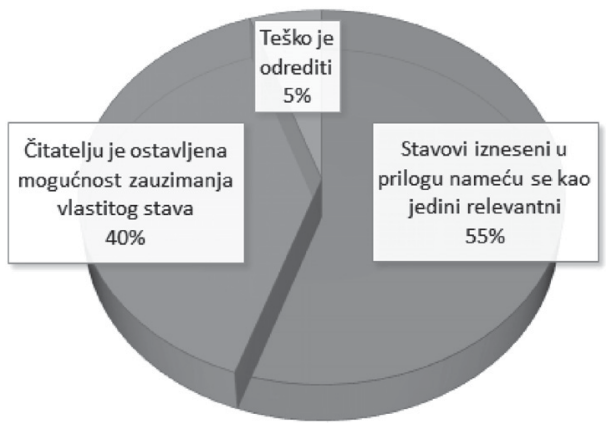

Grafikon 52: „Otvorenost” prema stavovima čitatelja - Večernji list

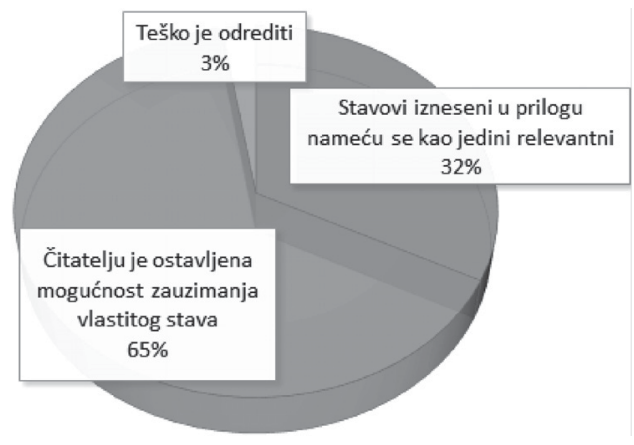

Grafikon 53: „Otvorenost” prema stavovima čitatelja - Index.hr

\section{ZAKLJUČNA RAZMATRANJA}

Uspoređujući četiri online portala analizom medija, uočavamo kako hrvatski online portali imaju pristran stav prema temi iseljavanja, dok to nije slučaj s Deutsche Welleom (koji je njemački medijski servis), koji pak pokazuje deficite u smislu da ni u jednome članku, za razliku od hrvatskih u kontekstu promatrane teme, ne dopušta kritiku niti rasvjetljava ulogu Njemačke u fenomenu iseljavanja. Članci portala 24sata, Večernji list i Index.hr kritički su nastrojeni, fokusiraju se na prezentiranje negativne slike ostanka u Hrvatskoj, dok Deutsche Welle objavljuje članke koji imaju informativno-edukativnu svrhu, ponajviše svojim načinom pisanja i nepristranim pristupom. Unatoč tome Deutsche Welle jedini je portal na kojemu nije zabilježeno prezentiranje pozitivne slike Hrvatske, za razliku od preostalih portala. Deutsche Welle, Index.hr, Večernji list za izvore najčešće biraju neimenovane izvore, na koje se djelomično ili u potpunosti 
oslanjaju, dok 24sata ipak ima najveći udio članaka u kojima nema neimenovanih izvora, to jes, sve iznesene informacije su provjerljive. Ipak, sva tri portala pružaju jednostran pristup tematici koju obrađuju. U člancima je vidljivo kako se iznose jedan ili više izvora koji zastupaju samo jednu stranu, što može upućivati na sugestivnost članaka. Ponovno, Deutsche Welle bilježi najveći udio članaka koji donose i drugi izvor koji zastupa i suprotnu stranu, dok to kod hrvatskih portala nije slučaj. Pri biranju izvora, to jest osoba koje će davati izjavu i koje će jamčiti za točnost onoga što je rečeno, jedino Večernji list ima najveći postotak konzultiranja s osobama koje još žive u Republici Hrvatskoj, dok drugi portali temelje svoje informacije na izjavama iseljenika, što podrazumijeva daljnju jednostranost i promoviranje određenog mišljenja ili uvjerenja prema čitateljima.

Citati koji su preuzeti iz razgovora s iseljenicima, stručnjacima, političarima i ljudima koji još žive u Hrvatskoj, imaju negativan ton, ili neutralan, no pozitivan stav prema ostanku u Hrvatskoj ne prevladava ni na jednom portalu. Kako se plasira negativna slika naspram ostanka u Hrvatskoj, pokazuju i komentari na društvenim mrežama, koji se nalaze ispod svakog članaka koji smo podvrgnuli analizi (osim DW-a, koji ne daje mogućnost komentara). Naime, komentari se najviše odnose na potrebu za iseljenjem iz Hrvatske, nezadovoljstvo sustavom u cjelini ili pak na izjave iseljenika o boljem životu izvan Hrvatske, a u manjoj mjeri komentari izražavaju realnu sliku o iseljeničkim zemljama te se preuveličavaju blagodati drugih država. Irska i Njemačka su zemlje o kojima se najviše govori, uz poneke koje se spominju vezano uz određen kontekst članka, poput Austrije i Švedske, a tekstovi su subjektivne prirode, s izuzetkom portala Deutsche Welle koji, prema našoj analizi, ima najobjektivnije tekstove, dok su tekstovi portala Index.hr podjednako su subjektivni i objektivni.

Svi članci temu obrađuju površno, odnosno tematika nije potanko obrađena te se nameće previše subjektivnih stavova. Naslovi su usmjereni k privlačenju čitatelja, te su većinom senzacionalistički, a najmanje informativne prirode. 24sata i Index.hr u tekstovima najviše provlače osobne stavove, a daju premalo informacija, dok se Deutsche Welle i Večernji list trude donijeti jednak broj informacija i stavova. Ipak, Deutsche Welle daje čitateljima najveću mogućnost vlastitog interpretiranja članaka, bez iznošenja svojih stavova kao jedinih relevantnih, a Večernji list u odnosu na preostale portale najviše nameće svoje stavove kao jedino relevantne.

Kao razlozi iseljavanja najviše se spominju politika i društvo, a manji je naglasak na ekonomske aspekte iseljavanja, iako se razlika 
u plaćama svakako često komentira. Najviše se komentiraju pogrešne političke odluke, kriza morala, nepovjerenje u institucije države, sustav i općenitu nesigurnost spram budućnosti, najčešce povezane uz percepciju nedovoljne borbe protiv nepotizma, korupcije i klijentizma.

Naslovi su senzacionalističke naravi, privlače čitatelje, ali ne reflektiraju tekst koji se ispod njih nalazi. Reakcije u komentarima koje su u velikom broju negativne pokazuju da se komentar nastavlja u sličnom tonalitetu u kojem je napisan i članak; s druge strane, stavlja se naglasak na nabrajanje svih aspekata negativnosti ostanka u Hrvatskoj i naglašava mogućnost boljitka iseljavanjem u drugu zemlju.

Teme poput migrantskih mreža koje pospješuju iseljavanje, strukturni problemi još iz vremena Jugoslavije i brojne druge se i ne spominju, što je znak da je fokus članaka na kritici politike i društva, ali ne i na obrađivanju problema iz svih aspekata. Zbog toga se može zaključiti kako hrvatski mediji jesu pristrani pri prikazivanju teme iseljavanja, jer je vidljivo da su stavovi, odabir osoba za razgovore i citate te subjektivnost prisutni u gotovo svakom od 152 analizirana članka.

Na kraju želimo napomenuti da analizirani online portali Večernji lista, 24sata, Index.hr i Deutsche Welle nisu u većoj ili manjoj mjeri pristrani od ostalih online portala u Hrvatskoj, niti postoji studija koja bi na to ukazivala. Naša analiza omogućuje samo usporedbu između ova četiri portala međusobno. Naglašavamo da našom analizom ni na koji način ne pogodujemo ni jednoj medijskoj kući niti surađujemo s bilo kojom od njih te da smo analizu napravili prema našim najboljim saznanjima i znanstvenom etičkom kodeks.

Na posljetku svakako uočavamo i pozitivnu ulogu koji igraju mediji u hrvatskom društvu, o čemu svjedoči činjenica da su mediji otvorili više ključnih društvenih tema od samih institucija i službi kojima je to u opisu posla te da svakako djeluju i kao konstruktivan društveni korektiv. 
Tado Jurić, Lucija Kardaš, Anja Bakota, Medijska analiza sadržaja online medija ...

\section{MEDIA ANALYSIS OF ONLINE MEDIA CONTENTS ON THE PHENOMENON OF CURRENT EMIGRATION FROM CROATIA}

\section{Summary}

By comparing the four Croatian online media portals and their impact on the perception of emigration through media analysis, it is evident that Croatian portals have biased attitudes towards emigration, while this is not the case with Deutsche Welle, a German media service. The articles of the 24sata, Večernji list and Index. $\mathrm{hr}$ are critical, focusing on presenting a negative image of living and staying in Croatia, while Deutsche Welle publishes articles that have informational and educational purpose, mostly written with an unbiased approach. Deutsche Welle is the only media without presentation of a positive image of Croatia, as opposed to the remaining web media portals. Deutsche Welle, Index.hr, Večernji list are choosing unnamed sources as main source of information, while the 24 sata still has the largest share of articles in which there are no unnamed sources of all three portals, all information in the articles are verifiable. The articles show that there are one or more sources representing only one side, which may refer to the suggestiveness of articles. Again, Deutsche Welle records the largest share of the articles that bring another source that represents the opposite side, while in the Croatian media it is not the same. Večernji list has the highest percentage of consultation with people who are still living in the Republic of Croatia while other portals base their information on the statements of emigrants, which implies promotion of certain opinions or beliefs towards readers.

Quotations from conversations with immigrants, experts, politicians and people who still live in Croatia have a negative tone, or neutral, however, the positive attitude towards staying in Croatia is not represented in any online media network. To show a negative image of staying in Croatia, they also show comments on social networks, which are placed below the articles. The comments mostly talk about leaving Croatia, expressing dissatisfaction with the system or the statements of emigrants about better life outside of Croatia. Few of them express a realistic picture of the emigrant countries and exaggerate the blessings of other states. Ireland and Germany are the countries mostly discussed.

The headlines aim at attracting readers. Most are sensationalist without informative nature. 24sata and Index.hr through articles are retrieving personal attitudes and little information, while Deu- 
tsche Welle and Večernji list are trying to bring an equal number of information and attitudes. Deutsche Welle gives readers the greatest opportunity to interpret their articles without expressing their views as the only relevant ones, and Večernji list from the remaining media imposes their opinions as the only relevant one. The main reasons for emigration are mostly politics and society, and there is a small emphasis on the economic sphere of emigration. Most articles discuss the political decisions, the crisis of morale, the uncertainty in the state, the system and general uncertainty about the future, nepotism, corruption, exploitation, but also inefficiency of the state itself, and disabling workers to go to other cities, to try to improve their financial situation. Issues such as the Croatian lobbying for emigration or the emigration network are not mentioned, which is a sign that the focus of articles is on criticism of politics and society, but not on dealing with consecutive issues which must be viewed from all aspects. It is possible to conclude that Croatian media are biased in displaying the topic of emigration, as it is evident that attitudes, the choice of interviewees, quotes, and subjectivity are present, with the superficial treatment of problems.

The headlines are sensationalistic, attract readers, and they reflect the text. Negative reactions in comments below articles show that the commentary continues in a similar tonality in which the article was written, and emphasis is placed on listing of all of the aspects of the negatives of staying in Croatia and moving to another country as a better option.

Keywords: emigration, Croatia, media, negative influence, web portals, one-sidedness, media influence

POPIS LITERATURE

Habermas, J. (1962.) The Structural Transformation of the Public Sphere, ISBN 0-262-58108-6

Kunczik, M. i Zipfel, A. (2006.): Uvod u znanost o medijima i komunikologiju. Zagreb: Zaklada Friedrich Ebert

Jurić, T. (2017.): Suvremeno iseljavanje Hrvata u Njemačku: karakteristike i motivi. Migracijske i etničke teme, 33, 3, Zagreb, 337-371.

Jurić, T. (2018.): Iseljavanje Hrvata u Njemačku - Gubimo li Hrvatsku?. Zagreb: Školska knjiga

Rešetar, T. (2018.): Utjecaj medija na iseljavanje stanovništva iz Republike Hrvatske. Koprivnica: Sveučilište Sjever

Tanjić, Ž. (2017.) Podijeljenosti u hrvatskom društvu: mogući uzroci i posljedice u perspektivi Ivana Rogića i Željka Mardešića, Bogoslovska smotra, Zagreb, 87 (2017.) 3, 659-673

Valković, J. (2016.), Utjecaj medija na socijalizaciju. KBF, Zagreb Teologija u Rijeci, Zagreb. 99-116. 
Tado Jurić, Lucija Kardaš, Anja Bakota, Medijska analiza sadržaja online medija ...

Online izvori

Večernji list (38 članaka)

1. Zar ćemo mirno gledati kako se gasi život u Dalmatinskoj zagori? https://www.vecernji.hr/vijesti/oslobodili-smo-domovinu-od-okupacije-onih-koji-je-nisu-znali-voljeti-ili-su-mislili-da-smiju-otimati-1262439

2. Hrvatska i dalje najprivlačnija radnicima iz $\mathrm{BiH}$, hrvatski radnici najviše žele u Njemačku https://www.vecernji.hr/biznis/hrvatska-i-dalje-najprivlacnija-radnicima-iz-bih-hrvatski-radnici-najvise-zele-u-njemacku-1263082

3. U Hrvatskoj je odlično ako imaš dobar posao https://www.vecernji.hr/ vijesti/u-hrvatskoj-je-odlicno-ako-imas-dobar-posao-1263647

4. U vukovarske osnovne škole upisano 72 prvašića manje https://www. vecernji.hr/vijesti/u-vukovarske-osnovne-skole-upisano-72-prvasicamanje-1267658

5. Evo koliko Hrvati koji rade u Njemačkoj pošalju novca nazad u domovinu https://www.vecernji.hr/biznis/iz-njemacke-na-bankovne-racuneu-hrvatskoj-uplaceno-cak-187-milijuna-eura-1268122

6. Konobar u Njemačkoj ima 2000 eura, stan i hranu. Kod nas zaradi 7500 kuna https://www.vecernji.hr/vijesti/konobar-u-njemackoj-ima2000-eura-stan-i-hranu-kod-nas-zaradi-7500-kuna-1268618

7. Obitelj Zirdum: Da nam država ne plaća pola rate kredita, već bismo bili u Irskoj https://www.vecernji.hr/vijesti/obitelj-zirdum-zbog-nizerate-nismo-se-odselili-u-irsku- 1268845

8. Mogu li i besplatni stanovi zadržati mlade? https://www.vecernji.hr/ premium/mogu-li-i-besplatni-stanovi-zadrzati-mlade- 1268842

9. Sin mu napustio Hrvatsku: Slavonac napisao pjesmu koja je rastužila mnoge https://www.vecernji.hr/vijesti/sin-mu-napustio-hrvatsku-slavonac-napisao-pjesmu-koja-je-rastuzila-mnoge-1269111

10. Tko su domoljubi u ovoj državi? https://www.vecernji.hr/vijesti/tkosu-domoljubi-u-ovoj-drzavi-1269281

11. Irci traže radnike u Hrvatskoj, iznenadio ih golemi interes za jedno zanimanje https://www.vecernji.hr/vijesti/irci-traze-radnike-u-hrvatskojiznenadio-ih-ogroman-interes-za-jedno-zanimanje-1269608

12. Hrvati, dobrodošli ste u Irsku, kod nas niste stranci https://www.vecernji.hr/premium/hrvati-dobrodosli-ste-u-irsku-kod-nas-niste-stranci- 1270480

13. Slavonija i Lika umiru - živi se u Zagrebu i na obali https://www. vecernji.hr/vijesti/slavonija-i-lika-umiru-zivi-se-u-zagrebu-i-na-obali-1270591

14. Potresna priča Slavonca: 'Ako si mlad i pošten, ne možeš to gledati' https://www.vecernji.hr/vijesti/potresna-prica-slavonca-ako-si-mladi-posten-ne-mozes-to-gledati- 1272844

15. Mladi žive lošije od svojih roditelja, a otežan im je i pristup fakultetima https://www.vecernji.hr/vijesti/mladi-zive-losije-od-svojih-roditelja-aotezan-im-je-i-pristup-fakultetima- 1273306

16. Hrvati se sele u Irsku, Njemačku..., a evo kamo idu građani iz bogatih europskih zemalja https://www.vecernji.hr/vijesti/i-bogati-se-sele-finci-u-svedsku-britanci-u-irsku-nijemci-u-francusku-1273368 
17. Nova hit-destinacija među liječnicima: Ovdje se može živjeti s jednom plaćom https://www.vecernji.hr/vijesti/nova-hit-destinacija-me-ulijecnicima-ovdje-se-moze-zivjeti-s-jednom-placom-1274049

18. Hrvatica preselila u Njemačku: Sretna sam tu, naša država ne funkcionira https://www.vecernji.hr/vijesti/hrvatica-preselila-u-njemackusretna-sam-tu-nasa-drzava-ne-funkcionira- 1274637

19. Nude stalno zaposlenje s plaćom od $11.000 \mathrm{kn}$, no nitko ne želi u Slavoniju https://www.vecernji.hr/vijesti/nude-stalno-zaposlenje-s-placom-od-11-000-kn-no-nitko-ne-zeli-u-slavoniju-1274656

20. Iz Njemačke došli u Slavoniju: 'Budućnost naše djece je ovdje' https:// www.vecernji.hr/vijesti/iz-njemacke-dosli-u-slavoniju-ovo-smo-zeljelinapokon-smo-sretni-1275400

21. Iz Hrvatske se iselilo 14\% stanovnika https://www.vecernji.hr/vijesti/ iz-hrvatske-se-iselilo-14-stanovnika-1275977

22. 'Za 10 sati rada na dan davali $3000 \mathrm{kn}$ plaće i sad im nema tko raditi' https://www.vecernji.hr/vijesti/za-10-sati-rada-na-dan-davali3000-kn-place-i-sad-im-nema-tko-raditi-1276605

23. Tri djevojke traže pomoć od Clintona: 'Teško nam je gledati kako ljudi odlaze iz naše zemlje' https://www.vecernji.hr/vijesti/tri-djevojke-traze-pomoc-od-clintona-tesko-nam-je-gledati-kako-ljudi-odlaze-iz-nasezemlje-1277433

24. Iseljenici dobrodošli natrag - da biste dobili državljanstvo, nećete više morati znati hrvatski jezik https://www.vecernji.hr/vijesti/iseljenicidobrodosli-natrag-da-bi-dobili-drzavljanstvo-necete-vise-morati-znatihrvatski-jezik-1278680

25. Većina se iseljava zbog društvene nepravde, a ne financijskih razloga https://www.vecernji.hr/premium/vecina-se-iseljava-zbog-drustvenenepravde-a-ne-financijskih-razloga- 1279245

26. 'Ako u tri-četiri godine iseli sedam posto stanovništva, to nije nešto što se događa slučajno' https://www.vecernji.hr/vijesti/ako-u-tri-cetiri-godine-iseli-sedam-posto-stanovnistva-to-nije-nesto-sto-se-doga-aslucajno-1279396

27. Hoće li Hrvati od Hrvatske učiniti 'reliquiae reliquiarum'? https:// www.vecernji.hr/premium/hoce-li-hrvati-od-hrvatske-uciniti-reliquiaereliquiarum-1279852

28. Alarmantno: Zaposleno 100.000 mladih manje nego prije deset godina https://www.vecernji.hr/vijesti/me-u-zaposlenima-104-tisuce-mladihmanje-nego-2007-1280641

29. Vratila se u Hrvatsku pa je zadesila pravna muka: Uzeli su mi 10 najljepših godina života https://www.vecernji.hr/vijesti/vratila-se-uhrvatsku-pa-je-zadesila-pravna-muka-u-bitke-na-sudu-duge-10-godina-ulozila-40-000-eura-1281991

30. Mala općina u Hrvatskoj kao primjer kako zadržati mlade obitelji https://www.vecernji.hr/vijesti/mala-opcina-u-hrvatskoj-kao-primjer-kako-zadrzati-mlade-obitelji-1283266

31. Država je zla majka: Zato sam odlučio emigrirati https://www.vecernji. hr/kultura/drzava-je-zla-majka-zato-sam-odlucio-emigrirati-1284513 
Tado Jurić, Lucija Kardaš, Anja Bakota, Medijska analiza sadržaja online medija ...

32. Škoda traži radnike u Hrvatskoj: 'Toliko koliko nude mogu zaraditi i u Hrvatskoj, https://www.vecernji.hr/vijesti/skoda-trazi-radnike-uhrvatskoj-toliko-koliko-nude-mogu-zaraditi-i-u-hrvatskoj-1284387

33. Kakva će biti Hrvatska 2051. https://www.vecernji.hr/vijesti/kakvace-biti-hrvatska-2051-1284613

34. Bijela kuga nas sve rastužuje. Kome je normalno iseljavanje mladih, taj ima ozbiljan problem https://www.vecernji.hr/showbiz/bijela-kuganas-sve-rastuzuje-kome-je-normalno-iseljavanje-mladih-taj-ima-ozbiljan-problem-1285639

35. Godinama je držao kiosk u Puli, a onda otišao u Njemačku i sada zarađuje 'previše' https://www.vecernji.hr/vijesti/godinama-je-drzao-kiosk-upuli-a-onda-otisao-u-njemacku-sada-je-cijenjeni-inzenjer-1285969

36. Mladi neurokirurg iz najskuplje bolnice na svijetu odlučio se vratiti u Hrvatsku https://www.vecernji.hr/vijesti/mladi-neurokirurg-se-iznajskuplje-bolnice-na-svijetu-odlucio-vratiti-u-hrvatsku-1286811

37. Razmišljate li o odlasku u Njemačku? Nakon ovog upozorenja, razmislite još jednom https://www.vecernji.hr/vijesti/razmisljate-o-odlaskuu-njemacku-nakon-ovog-upozorenja-razmislite-jos-jednom-1287279

38. France 24 snimio prilog o iseljavanju: 'Katastrofa. Ne valja Hrvatska ništa' https://www.vecernji.hr/vijesti/france-24-snimio-prilog-o-iseljavanju-katastrofa-ne-valja-hrvatska-nista-1288737

\section{Portal Indeks.hr (40članaka)}

1. HDZ-ov zastupnik: Mladi odlaze iz Hrvatske zbog teških roditelja koji im zagorčavaju život https://www.index.hr/vijesti/clanak/hdzov-zastupnik-mladi-odlaze-iz-hrvatske-zbog-teskih-roditelja-koji-im-zagorcavaju-zivot/2004199.aspx

2. Medicinska sestra preselila u Irsku: Zarađujem puno više, možemo si priuštiti i Tenerife https://www.index.hr/vijesti/clanak/medicinskasestra-preselila-u-irsku-zaradjujem-puno-vise-mozemo-si-priustiti-itenerife/2003995.aspx

3. Karta koja govori baš sve o propasti Hrvatske https://www.index.hr/vijesti/clanak/karta-koja-govori-bas-sve-o-propasti-hrvatske/2004218. aspx

4. Zbog čega ljudi bježe iz Hrvatske, vlastitih roditelja ili HDZ-a? https:// www.index.hr/vijesti/clanak/zbog-cega-ljudi-bjeze-iz-hrvatske-vlastitih-roditelja-ili-hdza/2004253.aspx

5. Hrvatski radnici u Njemačkoj u strahu: „Ne znam kako ćemo podnijeti ovakav udarac" https://www.index.hr/vijesti/clanak/hrvatski-radnici-u-njemackoj-u-strahu-ne-znam-kako-cemo-podnijeti-ovakav-uda$\mathrm{rac} / 2004609$.aspx

6. Stručnjaci o nedostatku radne snage: Prijeti nam izumiranje i slom mirovina https://www.index.hr/vijesti/clanak/strucnjaci-o-nedostatku-radne-snage-prijeti-nam-izumiranje-i-slom-mirovina/2005119.aspx

7. Iz Hrvatske želi pobjeći 93\% građana https://www.index.hr/vijesti/clanak/iz-hrvatske-zeli-pobjeci-93-gradjana/2005760.aspx 
8. Bečki institut izračunao: Hrvatska je od 1990. izgubila 13 posto stanovništva https://www.index.hr/vijesti/clanak/becki-institut-izracunaohrvatska-je-od-1990-izgubila-13-posto-stanovnistva/2007456.aspx

9. Njemačka traži više od milijun radnika, zaposlit će vas i ako nemate pojma o poslu https://www.index.hr/vijesti/clanak/njemacka-trazi-vise-odmilijun-radnika-zaposlit-ce-vas-i-ako-nemate-pojma-o-poslu/2007875. aspx

10. Novi katastrofalni podaci: Sve više umrlih, sve manje rođenih. U 10 godina nestao grad veći od Splita https://www.index.hr/vijesti/clanak/ novi-katastrofalni-podaci-sve-vise-umrlih-sve-manje-rodjenih-u-10-godina-nestao-grad-veci-od-splita/2012549.aspx

11. Njemački radio o životu na hrvatskoj obali: Škole s par učenika, usamljeni starci i mladi koji bježe https://www.index.hr/vijesti/clanak/ njemacki-radio-o-zivotu-na-hrvatskoj-obali-skole-s-par-ucenika-usamljeni-starci-i-mladi-koji-bjeze/2007794.aspx

12. U Otvorenom se sukobili Strmota i Nada Murganić: „Ovo oko demografije je igrokaz" https://www.index.hr/vijesti/clanak/u-otvorenom-se-sukobili-strmota-i-nada-murganic-ovo-oko-demografije-je-igrokaz/2008461. aspx

13. Ovaj graf pokazuje kako Hrvatska propada i zašto Irska privlači useljenike https://www.index.hr/vijesti/clanak/ovaj-graf-pokazuje-kakohrvatska-propada-i-zasto-irska-privlaci-useljenike/2012027.aspx

14. Njemačkoj kronično fali osoblja u bolnicama, traže radnike i nude povlastice https://www.index.hr/vijesti/clanak/njemackoj-kronicno-faliosoblja-u-bolnicama-traze-radnike-i-nude-povlastice/2015094.aspx

15. U 2017. iz Hrvatske je svaki dan odlazilo po 130 ljudi https://www. index.hr/vijesti/clanak/u-2017-iz-hrvatske-je-svaki-dan-odlazilo-po130-ljudi/2016027.aspx

16. Lani je samo u Njemačku pobjegao grad veličine Đakova https://www. index.hr/vijesti/clanak/lani-je-samo-u-njemacku-pobjegao-grad-velicine-djakova/2016046.aspx

17. Der Standard: Egzodus radnika postaje sve veći problem za istočnu Europu https://www.index.hr/vijesti/clanak/der-standard-egzodusradnika-postaje-sve-veci-problem-za-istocnu-europu/2014701.aspx

18. Mladi Slavonci dolaze kući vjenčati se kako bi plaćali manji porez u Njemačkoj https://www.index.hr/vijesti/clanak/mladi-slavonci-dolaze-kucivjencati-se-kako-bi-placali-manji-porez-u-njemackoj/2018770.aspx

19. Slovenci razvijaju mrežu pametnih sela, pozivaju mlade na ostanak u njima https://www.index.hr/vijesti/clanak/slovenci-razvijaju-mrezupametnih-sela-pozivaju-mlade-na-ostanak-u-njima/2020099.aspx

20. Ravnatelji škola u strahu uoči početka školske godine: Stanje je alarmantno https://www.index.hr/vijesti/clanak/ravnatelji-skola-u-strahu-uoci-pocetka-skolske-godine-stanje-je-alarmantno/2020342.aspx

21. Busevi za Njemačku puni, uplakane majke ispraćaju djecu: „Ovo više nema smisla" https://www.index.hr/vijesti/clanak/busevi-za-njemacku-puni-uplakane-majke-ispracaju-djecu-ovo-vise-nema-smisla/2020621.aspx 
22. Njemačkoj nedostaje 800.000 radnika, njemački konzulati zatrpani zahtjevima https://www.index.hr/vijesti/clanak/njemackoj-nedostaje-800000-radnika-njemacki-konzulati-zatrpani-zahtjevima/2021185. aspx

23. Novi podaci otkrili: Hrvatska preživljava od novca ljudi koji su pobjegli iz nje https://www.index.hr/vijesti/clanak/novi-podaci-otkrili-hrvatska-prezivljava-od-novca-ljudi-koji-su-pobjegli-iz-nje/2021942.aspx

24. Imamo podatke: Broj učenika u osnovnim školama od 1996. pao za više od 100.000 https://www.index.hr/vijesti/clanak/imamopodatke-broj-ucenika-u-osnovnim-skolama-od-1996-pao-za-viseod-100000/2022158.aspx

25. Priča mladog Slavonca: „Kad mladi, pošteni ljudi ovo vide odmah bježe u Irsku" https://www.index.hr/vijesti/clanak/prica-mladog-slavoncakad-mladi-posteni-ljudi-ovo-vide-odmah-bjeze-u-irsku/2026928.aspx

26. Hrvati se najviše u EU muče uskladiti radne i obiteljske obaveze https:// www.index.hr/vijesti/clanak/hrvati-se-najvise-u-eu-muce-uskladitiradne-i-obiteljske-obaveze/2028042.aspx

27. Njemačka obitelj doselila u Slavoniju: „Čudno nas gledaju” https:// www.index.hr/vijesti/clanak/njemacka-obitelj-doselila-u-slavonijucudno-nas-gledaju/2029560.aspx

28. Austrijski list: Ljudi odlaze iz Hrvatske jer bježe od neslobode https:// www.index.hr/vijesti/clanak/austrijski-list-ljudi-odlaze-iz-hrvatskejer-bjeze-od-neslobode/2029942.aspx

29. Kolinda: Nije se dobro koncentrirati na afere, to tjera ljude iz zemlje https://www.index.hr/vijesti/clanak/kolinda-nije-se-dobro-koncentrirati-na-afere-to-tjera-ljude-iz-zemlje/2031328.aspx

30. Kolindina logika: Ljudi ne bježe zbog afera, nego jer se o njima piše https://www.index.hr/vijesti/clanak/kolindina-logika-ljudi-ne-bjezezbog-afera-nego-jer-se-o-njima-pise/2031414.aspx

31. Biskupi napali vladu, sindikate, sudstvo... https://www.index.hr/vijesti/clanak/biskupi-napali-vladu-sindikate-sudstvo/2034636.aspx

32. Radnici iz Hrvatske sele se u Alpe. Plaće i do 3500 eura https://www. index.hr/vijesti/clanak/radnici-iz-hrvatske-sele-se-u-alpe-place-i-do3500-eura/2034898.aspx

33. Upozorenje poduzetnika: U iduće 4 godine otići će 300.000 ljudi. To će biti kraj https://www.index.hr/vijesti/clanak/upozorenje-poduzetnikau-iduce-4-godine-otici-ce-300000-ljudi-to-ce-biti-kraj/2040440.aspx

34. Voice of America piše o egzodusu Hrvata i HDZ-u koji ga ne može spriječiti https://www.index.hr/vijesti/clanak/voice-of-america-pise-oegzodusu-hrvata-i-hdzu-koji-ga-ne-moze-sprijeciti/2040534.aspx

35. Biskup u Vukovaru: Geni, geni, hrvatski. Nadam se da mi neće isključiti mikrofon https://www.index.hr/vijesti/clanak/biskup-u-vukovarugeni-geni-hrvatski-nadam-se-da-mi-nece-iskljuciti-mikrofon/2043399. aspx

36. Ovo su hrvatski gradovi u koje se doselilo više ljudi nego što ih se iselilo https://www.index.hr/vijesti/clanak/ovo-su-hrvatski-gradovi-u-kojese-doselilo-vise-ljudi-nego-sto-ih-se-iselilo/2044299.aspx 
37. Novi izvještaj Europske komisije o Hrvatskoj nije uobičajeni horor https://www.index.hr/vijesti/clanak/novi-izvjestaj-europske-komisije-o-hrvatskoj-nije-uobicajeni-horor/2044636.aspx

38. Njemački list: Hrvatska pati od velikog odljeva mozgova, evo kako ga zaustaviti https://www.index.hr/vijesti/clanak/njemacki-list-hrvatska-pati-od-velikog-odljeva-mozgova-evo-kako-ga-zaustaviti/2044273. aspx

39. Kolinda kritizirala vladu: Moramo demografski misliti u svemu što radimo https://www.index.hr/vijesti/clanak/kolinda-kritizirala-vladumoramo-demografski-misliti-u-svemu-sto-radimo/2047210.aspx

40. MMF: Iseljavanje Hrvata ugrožava mirovine i zdravstvo, srežite javnu upravu https://www.index.hr/vijesti/clanak/mmf-iseljavanje-hrvataugrozava-mirovine-i-zdravstvo-srezite-javnu-upravu/2049079.aspx

\section{Deutsche Welle (25 članaka)}

1. Hrvatska ne poštuje mlade, zato i demografski tone https://www. dw.com/hr/hrvatska-ne-po\%C5\%Altuje-mlade-zato-i-demografskitone/a-44279729

2. Bez odgovora na izazove novog vala iseljavanja https://www.dw.com/ $\mathrm{hr} / \mathrm{bez}$-odgovora-na-izazove-novog-vala-iseljavanja/a-42447626

3. Novi iseljenici iz Hrvatske: Odlaze oni koji već imaju posao https://www. dw.com/hr/novi-iseljenici-iz-hrvatske-odlaze-oni-koji-ve\%C4\%87-imaju-posao/a-41829200

4. Hrvatski liječnici masovno odlaze u tuđinu: „Odlazak je racionalna odluka” https://www.dw.com/hr/hrvatski-lije\%C4\%8Dnici-masovno-odlaze-u-tu\%C4\%91inu-odlazak-je-racionalna-odluka/a-37519261

5. Iseljenici novoga kova: Idemo u Njemačku, želimo se dokazati! https:// www.dw.com/hr/iseljenici-novoga-kova-idemo-u-njema\%C4\%8Dku\%C5\%BEelimo-se-dokazati/a-18516360

6. Njemačka za Hrvate „obećana zemlja”? https://www.dw.com/hr/ njema\%C4\%8Dka-za-hrvate-obe\%C4\%87ana-zemlja/a-17282902

7. Mladi Hrvati u potrazi za boljim životom https://www.dw.com/hr/mladi-hrvati-u-potrazi-za-boljim-\%C5\%BEivotom/a-16307458

8. U Hrvatskoj neće imati tko raditi? https://www.dw.com/hr/u-hrvatskoj-ne\%C4\%87e-imati-tko-raditi/a-42733486

9. Petrinjska obitelj: naša prva godina u Njemačkoj https://www. dw.com/hr/petrinjska-obitelj-na\%C5\%Ala-prva-godina-unjema\%C4\%8Dkoj/a-42126087

10. Korupcija uništava Hrvatsku, ali borba protiv nje ne postoji https:// www.dw.com/hr/korupcija-uni\%C5\%Al tava-hrvatsku-ali-borba-protiv-nje-ne-postoji/a-42267624

11. „U Hrvatskoj uvijek moraš biti “nečiji” https://www.dw.com/hr/uhrvatskoj-uvijek-mora\%C5\%A1-biti-ne\%C4\%8Diji/a-41640229

12. Istočnoeuropske radnice prepolovile dnevnice hrvatskih njegovateljica https://www.dw.com/hr/isto\%C4\%8Dnoeuropske-radnice-prepolovile-dnevnice-hrvatskih-njegovateljica/a-41548012 
13. Hrvatski branitelj, umirovljeni policajac, gastarbajter „na crno” https:// www.dw.com/hr/hrvatski-branitelj-umirovljeni-policajac-gastarbajterna-crno/a-41428906

14. S diplomom u džepu - u Irsku! https://www.dw.com/hr/s-diplomomu-d\%C5\%BEepu-u-irsku/av-40746952

15. Zašto se Hrvatska treba bojati pada nezaposlenosti https:// www.dw.com/hr/za\%C5\%A1to-se-hrvatska-treba-bojati-padanezaposlenosti/a-37721689

16. Trbuhom za kruhom: u Irskoj se može živjeti od rada https:// www.dw.com/hr/trbuhom-za-kruhom-u-irskoj-se-mo\%C5\%BEe\%C5\%BEivjeti-od-rada/a-37388169

17. Hrvatska: Nezaposleni su davno otišli, sada odlaze sposobni https:// www.dw.com/hr/hrvatska-nezaposleni-su-davno-oti\%C5\%Alli-sadaodlaze-sposobni/a-36183828

18. Njemačka - da, ali ne po svaku cijenu https://www.dw.com/hr/ njema\%C4\%8Dka-da-ali-ne-po-svaku-cijenu/a-18699582

19. Neuspjeh balkanskih političara https://www.dw.com/hr/neuspjeh-balkanskih-politi\%C4\%8Dara/a-18650953

20. Njemačka je atraktivna za doseljenike https://www.dw.com/hr/ njema\%C4\%8Dka-je-atraktivna-za-doseljenike/a-17365468

21. Pravi razlozi odlazaka liječnika iz Hrvatske https://www.dw.com/hr/ pravi-razlozi-odlazaka-lije\%C4\%8Dnika-iz-hrvatske/a-45438861

22. Hrvati znaju raditi u Njemačkoj, ne znaju u Hrvatskoj? https://www. dw.com/hr/hrvati-znaju-raditi-u-njema\%C4\%8Dkoj-ne-znaju-uhrvatskoj/a-43739250

23. Masovni 'odljev mozgova's Balkana https://www.dw.com/hr/masovniodljev-mozgova-s-balkana/a-42774456

24. Rad u Njemačkoj - druga strana medalje https://www.dw.com/hr/radu-njema\%C4\%8Dkoj-druga-strana-medalje/a-38949899

25. „Moja djeca ovdje nemaju budućnost” https://www.dw.com/hr/mojadjeca-ovdje-nemaju-budu\%C4\%87nost/a-37513782

\section{Portal 24sata (36 članaka)}

1. 'Nisam požalio što sam otišao u Njemačku. Ne želim natrag' https:// m.24sata.hr/news/nisam-pozalio-sto-sam-otisao-u-njemacku-nezelim-natrag-599402

2. Adventski Kolindar: 24 razloga zašto ljudi odlaze iz Hrvatske https:// m.24sata.hr/blogbuster/adventski-kolindar-24-razloga-zasto-ljudiodlaze-iz-hrvatske-598744

3. Apstraktno domoljublje: HDZ nije sposoban ublažiti egzodus https:// m.24sata.hr/news/apstraktno-domoljublje-hdz-nije-sposoban-ublaziti-egzodus-598557

4. 'Nestajemo': Čak 449 općina i gradova bilježi pad broja ljudi... https:// m.24sata.hr/news/nestajemo-cak-449-opcina-i-gradova-biljezi-padbroja-ljudi-598330

5. Moj prijatelj je danas plakao, plakao jer ostaje dok svi odlaze https:// m.24sata.hr/blogbuster/moj-prijatelj-je-danas-plakao-plakao-jer-ostaje-dok-svi-odlaze-588170 
6. Potresna ispovijed Slavonca: 'Mladi to vide i zato odlaze...' https:// m.24sata.hr/news/potresna-ispovijed-slavonca-mladi-to-vide-i-zatoodlaze-592409

7. 'Ne mogu naći posao, odlazim tamo gdje mogu živjeti i raditi' https:// m.24sata.hr/news/ne-mogu-naci-posao-odlazim-tamo-gdje-moguzivjeti-i-raditi-590064

8. 'Rekao je da ide van jer više ne može, došlo mi je da zaplačem' https:// m.24sata.hr/news/rekao-je-da-ide-van-jer-vise-ne-moze-doslo-mi-jeda-zaplacem-589881

9. Je li to 'manjak domoljublja'? Ne, to je istinsko domoljublje https:// m.24sata.hr/kolumne/je-li-to-manjak-domoljublja-ne-to-je-istinskodomoljublje-589796

10. 'Moj sin je otišao u Njemačku jer nije htio ovdje životariti... https:// m.24sata.hr/news/moj-sin-je-otisao-u-njemacku-jer-nije-htio-ovdjezivotariti-589767

11. Uzroci iseljavanja: Zemlja nam je sve praznija zbog korupcije https:// m.24sata.hr/news/uzroci-iseljavanja-zemlja-nam-je-sve-praznija-zbogkorupcije-583534

12. 'Vani se novac krvavo zarađuje, ali živi se lagodnije nego doma' https:// m.24sata.hr/news/vani-se-novac-krvavo-zara-uje-ali-zivi-se-lagodnijenego-doma-583203

13. Zašto su radnici iselili? Ovdje zarade 6.000, a vani $14.400 \mathrm{kn}$ https:// m.24sata.hr/news/zasto-su-radnici-iselili-ovdje-zaradi-6-000-a-vani14-500-kn-584445

14. Iselila je i šesteročlana obitelj: ‘Živjeli smo od tatine plaće...' https:// m.24sata.hr/news/iselila-je-i-sesteroclana-obitelj-zivjeli-smo-od-tatine-place-583198

15. Hrvatska je u 10 godina ostala bez točno 204.300 stanovnika! https:// m.24sata.hr/news / hrvatska-je-u-10-godina-ostala-bez-tocno204-300-stanovnika-582997

16. 'Završio sam fakultet i bio bez posla. Otišao sam u Njemačku' https:// m.24sata.hr/news/zavrsio-sam-fakultet-i-bio-bez-posla-otisao-sam-unjemacku-580195

17. Kardinal Puljić: Ljudi iseljavaju zbog korupcije i nejednakosti https:// m.24sata.hr/news/kardinal-puljic-ljudi-iseljavaju-zbog-korupcije-inejednakosti-580249

18. 'Od rujna smo izgubili cijeli razred, a djeca i dalje odlaze...' https:// m.24sata.hr/news/od-rujna-smo-izgubili-cijeli-razred-a-djeca-i-daljeodlaze-579828

19. Plaća nam je 2,5 puta manja, a dizel skuplji nego Nijemcima... https:// m.24sata.hr/news/placa-nam-je-2-5-puta-manja-a-dizel-skuplji-negonijemcima-578986

20. Predsjednica: 'Jedino reforme jamče zaustavljanje iseljavanja' https:// m.24sata.hr/news/predsjednica-jedino-reforme-jamce-zaustavljanjeiseljavanja-579646

21. 'Htjela sam krenuti ispočetka u zemlji bez ustaša i partizana' https:// m.24sata.hr/news/odlucila-sam-krenuti-ispocetka-u-zemlji-bez-ustasa-i-partizana-578647 
22. 'Imao sam tri puta veću plaću, ali sam se vratio u Hrvatsku...' https:// m.24sata.hr/news/imao-sam-tri-puta-vecu-placu-ali-sam-se-vratio-uhrvatsku-578577

23. Priče iz prepunog autobusa: „Možda se i vratim, ali...” https://m.24sata. $\mathrm{hr} /$ news/price-iz-prepunog-autobusa-mozda-se-i-vratim-ali-579357

24. 'Zašto smo otišli iz Hrvatske? Uhljebi se bave sami sa sobom' https:// m.24sata.hr/news/zasto-smo-otisli-iz-hrvatske-uhljebi-se-bave-samisa-sobom-578235

25. 'U Hrvatsku se više se nećemo vratiti, samo želimo bolji život' https:// m.24sata.hr/news/u-hrvatsku-se-vise-se-necemo-vratiti-samo-zelimobolji-zivot-578177

26. 'Otišla sam jer su kod nas svi natječaji za poslove naštimani’ https:// m.24sata.hr/news/otisla-sam-jer-su-kod-nas-svi-natjecaji-za-poslovenastimani-578002

27. 'Ljudi iz Hrvatske ne bježe od siromaštva, nego od nepravde' https:// m.24sata.hr/news/ljudi-iz-hrvatske-ne-bjeze-od-siromastva-nego-odnepravde-577888

28. Turobna prognoza demografa Šterca: 'Nećemo se oporaviti!' https:// m.24sata.hr/news/turobna-prognoza-demografa-sterca-necemo-seoporaviti-577828

29. Zašto mladi iseljavaju? 'Teški roditelji zagorčavaju im život...' https:// m.24sata.hr/news/zasto-mladi-iseljavaju-teski-roditelji-zagorcavajuim-zivot-577846

30. 'Imala sam osjećaj da me moja Hrvatska iskoristila i ismijala' https:// m.24sata.hr/news/imala-sam-osjecaj-da-me-moja-zemlja-iskoristila-iismijala-577831

31. Istina o iseljavanju: Još pola milijuna ljudi moglo bi otići https:// m.24sata.hr/news/istina-o-iseljavanju-jos-pola-milijuna-ljudi-moglobi-otici-577807

32. Još jedna obitelj otišla u Irsku: 'Živimo bolje i s manje briga...' https:// m.24sata.hr/news/jos-jedna-obitelj-otisla-u-irsku-zivimo-bolje-i-smanje-briga-577682

33. Licemjerni političari nikako da shvate da su razlog iseljavanja https:// m.24sata.hr/kolumne/licemjerni-politicari-nikako-da-shvate-da-surazlog-iseljavanja-577291

34. Hrvati odlaze zbog korupcije, primitivizma, malih plaća... https:// m.24sata.hr/news/porazno-42-posto-iseljenika-ne-planira-se-vratitiu-hrvatsku-576899

35. Ništa se ne mijenja: Evo zašto svi masovno bježe iz Hrvatske https:// $\mathrm{m} .24$ sata.hr/kolumne/ne-promijenite-li-politiku-sutra-vise-neceteimati-s-kim-vladati-576576

36. Poražavajuće: Više od polovice najboljih učenika planira iseliti https:// $\mathrm{m} .24$ sata.hr/news/vise-od-pola-najboljih-ucenika-zeli-se-odseliti-izhrvatske-576522 